\title{
Polyphenols from Pennisetum glaucum grains induce MAP kinase phosphorylation and cell cycle arrest in human osteosarcoma cells
}

Abdelhafid Nani ${ }^{\mathrm{a}, \mathrm{b}, \mathrm{c}, *}$, Meriem Belarbi ${ }^{\mathrm{b}}$, Babar Murtaza $^{\mathrm{a}}$, Chahid Benammar $^{\mathrm{b}}, \quad$ Taha Merghoub $^{\mathrm{d}}$, Mickaël Rialland ${ }^{\mathrm{a}}$, Naim Akhtar Khan ${ }^{\mathrm{a}}$, Aziz Hichamia,

${ }^{a}$ U1231 INSERM/Université de Bourgogne-Franche Comté (UBFC)/Agro-Sup, Physiologie de la Nutrition \& Toxicologie, Dijon 21000, France

${ }^{b}$ Laboratory of Natural Products, University of Abou-Bekr Belkaid, Tlemcen 13000, Algeria

${ }^{c}$ Department of Natural and Life Sciences, African University Ahmed Draia, Adrar 01000, Algeria

${ }^{d}$ Department of Medicine, Memorial Sloan Kettering Cancer Center, New York, NY 10065, United States

\section{*Corresponding authors}

Aziz Hichami: aziz.hichami@u-bourgogne.fr

Abdelhafid Nani: nani.abdelhafid@univ-adrar.dz 


\begin{abstract}
1 Osteosarcoma is the most common bone tumor with a high prevalence among children and 2 adolescents. Polyphenols are widely investigated for their chemopreventive and 3 chemotherapeutic proprieties. In the present study, we explored the pro-apoptotic effects of 4 pearl millet, Pennisetum glaucum, phenolic compounds (PGPC) on osteosarcoma U-2OS cells. Our results show that PGPC induced U-2OS cells death, in a dose dependent manner, with an $\mathrm{IC}_{50}$ of $80 \mu \mathrm{g} / \mathrm{mL}$. Annexin-V and 7-AAD staining show that PGPC induced cell death mainly through caspase-dependent apoptosis as shown by a decrease in cell death when co-treated with pan-caspase inhibitor, N-benzyloxycarbonyl-Val-Ala-Asp-fluoromethylketone (z-VAD-fmk). PGPC caused an increase in cytoplasmic calcium associated with caspases activation and poly (ADP-ribose) polymerase PARP cleavage. Western blot analysis revealed that PGPC upregulated p38 MAPK and SAPK/JNK activity and inhibited c-SRC/AKT pathway. Finally, cell cycle analysis shows that PGPC decreased CDK2 and increased cyclin E expression, resulting in U-2OS cells accumulation in S phase. These results demonstrate that PGPC induce p38 MAPK and SAPK/JNK activation, and attenuate AKT activation, leading to cell cycle arrest and apoptosis in osteosarcoma U-2OS cells.
\end{abstract}

Key words: pearl millet; polyphenols; U-2OS cells; cell signaling; intracellular calcium; cell cycle arrest; apoptosis

Abbreviations: 3-MA, 3-Methyladenine; 5-FU, 5-Fluorouracil; AKT, Protein kinase B; Annexin V-APC/7-AAD, Annexin V-apoptosis -associated caspase/7-Aminoactinomycin D; BAPTA-AM, 1,2-Bis(2-aminophenoxy)ethane- $N, N, N^{\prime}, N^{\prime}$-tetraacetic acid tetrakis (acetoxymethyl ester); cdc2, yeast Cyclin-dependent kinase-2; CDK2, human Cyclin-dependent kinase-2; CDKs, cyclin-dependent kinases; CKIs, cyclin dependent kinase inhibitors; CQ, 
chloroquine; c-Src, Proto-oncogene tyrosine-protein kinase; EGTA, ethylene glycol-bis( $\beta$ aminoethyl ether)-N,N,N',N'-tetraacetic acid; ERK1/2, p44/42 MAPK; Fura-2 AM, fura-2acetoxymethylester; JAK 2, Janus kinase 2; LDH, lactate dehydrogenase; mTOR, mammalian target of rapamycin; p38 MAPK, p38 mitogen-activated protein kinases; p70 S6K, Ribosomal protein S6 kinase; p-CA, p-coumaric acid; PGPC, Pennisetum glaucum phenolic compounds, PI3-K, phospho-inositide 3-kinase; RuR, ruthenium red; SAPK/JNK, stress activated protein kinase/c-Jun N-terminal kinases; STAT3, Signal transducer and activator of transcription 3; TRAF2, tumor necrosis factor (TNF)-Receptor Associated Factor; TRAIL, tumor-necrosis-factor related apoptosis inducing ligand; XBP1, X box-bindingprotein 1; z-VAD-fmk, N-benzyloxycarbonyl-Val-Ala-Asp-fluoromethylketone.

\section{Introduction}

Osteosarcoma is the most common bone tumor with a high prevalence among children and adolescents (Mirabello, Troisi, \& Savage, 2009). Surgery and chemotherapy are the standard of care for osteosarcoma (Luetke, Meyers, Lewis, \& Juergens, 2014). However, besides resistance or low response to chemotherapeutic agents, chemotherapy is known for its toxicities including cardiomyopathy, encephalopathy, hearing loss, hemorrhagic cystitis and hypomagnesemia (Allison et al., 2012; Bakhshi \& Radhakrishnan, 2010; Cho et al., 2009; Marina, Gebhardt, Teot, \& Gorlick, 2004). Therefore, there is an increasing interest in dietderived agents for their potential chemopreventive properties. Epidemiological and preclinical studies suggest that dietary polyphenols possess cancer chemopreventive properties with less side effects and toxicities (Thomasset et al., 2007).

Impairment of programmed cell deaths and loss of normal cellular replication control are fundamental defects in cancer mainly due to signaling pathway alterations (Ouyang et al., 
2012; Roskoski, 2016). The escape from apoptosis, a hallmark characteristic of cancer cells, represents an important target for cancer prevention or therapy (Moore, Megaly, MacNeil, Klentrou, \& Tsiani, 2016). The serine/threonine kinase AKT, also known as protein kinase B $(\mathrm{PKB})$, is a proto-oncogene that regulates cancer cell division, growth, migration, survival, and resistance to chemo and radio-therapy (Fruman \& Rommel, 2014; Hanahan \& Weinberg, 2011). AKT acts as an upstream component of cell cycle progression promoters, including Signal transducer and activator of transcription 3 (STAT3) (Riemenschneider, Betensky, Pasedag, \& Louis, 2006), with direct regulation of apoptotic machinery (Downward, 2004). p53 is a transcription factor that regulates the balance between pro-apoptotic and antiapoptotic genes, and the activation of this protein is required for apoptosis and cell cycle arrest (Giono \& Manfredi, 2006; Linke, Clarkin, Di Leonardo, Tsou, \& Wahl, 1996; Vousden \& Prives, 2009).

Recently, many groups have demonstrated the anti-cancer properties of plant and food derived polyphenols by regulation of phospho-inositide 3-kinase (PI3K)/AKT related pathways (Banerjee, Kim, Krenek, Talcott, \& Mertens-Talcott, 2015; Darvin et al., 2015; Moore et al., 2016; T et al., 2016). Mango polyphenols, in part through the PI3K/AKT, have a chemotherapeutic potential against breast cancer (Banerjee et al., 2015). Polyphenols from Sorghum, a principal cereal food used besides millet in many countries, have been shown to suppress colon cancer growth and pulmonary metastasis in animal models by co-targeting Janus kinase 2 (JAK2)/STAT3 and PI3K/AKT/ mammalian target of rapamycin (mTOR) pathways (Darvin et al., 2015). Ferulic acid, a ubiquitous phenolic acid in cereals including millets, blocks cell cycle progression and induces apoptosis in 143B and MG63 osteosarcoma cells via blockage of PI3K/AKT pathway (Wang et al., 2016).

We have previously shown that pearl millet (Pennisetum glaucum) grains are rich in polyphenols. Moreover, p-coumaric and ferulic acids, which have been reported to exhibit 

96

antitumor and antimetastasic activities, are the most abundant phenolic compounds (Nani et al., 2015). In the present study we sought to investigate the mechanisms involved in the antitumor activity of Pennisetum glaucum phenolic compounds (PGPC) against the U-2OS osteosarcoma cell line.

\section{Materials and methods}

\subsection{Materials}

Grains of pearl millet were obtained from the region of Ouled Aïssa (174 km in the North of Adrar city and $70 \mathrm{~km}$ to the North-West of Timimoun, Algeria). RPMI 1640 medium and Lglutamine were purchased from Lonza Verviers SPRL (Verviers, Belgium). Fura-2 AM (fura2-acetoxymethylester) was procured from Life Technologies (France). Annexin V-APC/7AAD kit was purchased from Biolegend (France). Trypsin was purchased from Gibco (USA). RNase-A was purchased from Euromedex (France) and propidium iodide from Immunochemistry (USA). LDH kit was purchased from Abcam (France). All antibodies used for Western blot analysis are listed in Table 1. All other chemicals were purchased from Sigma (USA). (1) (1)

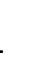
2 93 4 5 


\begin{tabular}{|c|c|c|c|c|}
\hline Antigen & dilution & $\begin{array}{l}\text { Source/ } \\
\text { Host }\end{array}$ & $\begin{array}{l}\text { Catalog } \\
\text { number }\end{array}$ & Company \\
\hline AKT & $1: 1000$ & Rabbit & 4685 & Cell Signaling Technology \\
\hline Caspase-8 & $1: 1000$ & Mouse & 9746 & Cell Signaling Technology \\
\hline Caspase-9 & $1: 1000$ & Mouse & 9508 & Cell Signaling Technology \\
\hline $\operatorname{cdc} 2(\mathrm{POH} 1)$ & $1: 1000$ & Mouse & 9116 & Cell Signaling Technology \\
\hline CDK2 & $1: 1000$ & Rabbit & 2546 & Cell Signaling Technology \\
\hline Cleaved PARP (Asp214) & $1: 1000$ & Rabbit & 9541 & Cell Signaling Technology \\
\hline c-Src (SRC 2) & $1: 500$ & Rabbit & sc-18 & Santa Cruz Biotechnology \\
\hline Cyclin A & $1: 500$ & Rabbit & sc-751 & Santa Cruz Biotechnology \\
\hline Cyclin E & $1: 500$ & Rabbit & sc-481 & Santa Cruz Biotechnology \\
\hline p38 MAPK & $1: 500$ & Rabbit & 622401 & BioLegend \\
\hline p53 & $1: 1000$ & Mouse & 2524 & Cell Signaling Technology \\
\hline $\begin{array}{l}\text { p70 S6K (Ribosomal } \\
\text { protein }\end{array}$ & $1: 1000$ & Rabbit & 2708 & Cell Signaling Technology \\
\hline Phospho -STAT3 (Ser 727) & $1: 200$ & Rabbit & sc-135649 & Santa Cruz Biotechnology \\
\hline Phospho-AKT (Ser473) & $1: 1000$ & Mouse & 4051 & Cell Signaling Technology \\
\hline Phospho-AKT (Thr308) & $1: 1000$ & Rabbit & 9275 & Cell Signaling Technology \\
\hline $\begin{array}{ll}\text { Phospho-p38 } & \text { MAPK } \\
\text { (Thr180/Tyr182) }\end{array}$ & $1: 1000$ & Rabbit & 4511 & Cell Signaling Technology \\
\hline Phospho-p53 (Ser46) & $1: 1000$ & Rabbit & 2521 & Cell Signaling Technology \\
\hline Phospho-p70 S6K (Thr389) & $1: 1000$ & Rabbit & 9205 & Cell Signaling Technology \\
\hline $\begin{array}{l}\text { Phospho-SAPK/JNK } \\
\text { (Thr183/Tyr185) }\end{array}$ & $1: 0000$ & Mouse & 9255 & Cell Signaling Technology \\
\hline SAPK/JNK & $1: 0000$ & Rabbit & 9252 & Cell Signaling Technology \\
\hline$\beta$-actin & $1: 5000$ & Mouse & sc-47778 & Santa Cruz Biotechnology \\
\hline p44/42 MAPK (ERK1/2) & $1: 1000$ & Rabbit & 9102 & Cell Signaling Technology \\
\hline $\begin{array}{l}\text { Phospho-p44/42 } \\
\text { (ERK1/2) }\end{array}$ & $1: 1000$ & Rabbit & 9100 & Cell Signaling Technology \\
\hline
\end{tabular}




\subsection{Preparation of polyphenol-rich extract}

102

103

104

105

106

107

108

109

110

111

112

113

114

115

116

117

118

119

120

121

122

123

124

The plant was recognized by a botanist (Pr Benabadji Nouri, Université Aboubekr Belkaïd, Tlemcen) of the Herbarium Center of the Faculty of Pharmacy (Tlemcen) which contained the voucher specimen (PM 1681). Phenolic extract from pearl millet was obtained as we have previously described (Nani et al., 2015). The defatted extract was evaporated, to dryness, under reduced pressure and then resuspended in PBS (Phosphate-buffered saline). Total phenolic content in plant extract were determined by Folin-Ciocalteu method (Folin \& Ciocalteu, 1927).

\subsection{Cell culture and viability assay}

U-2OS osteosarcoma cells were obtained from the American Type Culture Collection (ATCC, Rockville, USA). Cells were maintained in RPMI 1640 Medium supplemented with $10 \%$ heat inactivated fetal bovine serum (FBS), penicillin $(100 \mathrm{U} / \mathrm{ml})$, streptomycin (100 $\mu \mathrm{g} / \mathrm{ml})$, L-glutamine $(2 \mathrm{mM})$. The cell viability was investigated by the trypan blue exclusion test. Briefly, U-2OS osteosarcoma cells were seeded into 24 -well plate ( 3 x $10^{4}$ cells/well $)$ and incubated for $24 \mathrm{~h}$ in a humidified chamber containing $95 \%$ air and $5 \% \mathrm{CO}_{2}$. Cells were then treated with increasing concentrations of PGPC (from 20 to $100 \mu \mathrm{g} / \mathrm{mL}$ ) and p-coumaric acid (p-CA, from 5000 to $25000 \mu \mathrm{M}$ ). After $24 \mathrm{~h}$, cells were trypsinized and diluted in $0.5 \%$ trypan blue. Cells were then counted with a Malassez hemocytometer under the light microscope "Nikon".

\section{4. $\mathrm{LDH}$ cytotoxicity assay}

The lactate dehydrogenase (LDH) cytotoxicity assay was performed to measure cell membrane integrity and the release of lactate dehydrogenase (LDH) from the cytosol of damaged cells into the supernatant by using a commercial kit (Abcam, France), according to the manufacturer's instruction. Briefly, 1 x $10^{4}$ cells/100 $\mu \mathrm{L}$ were seeded in in 96-well plates. 
After $24 \mathrm{~h}$ incubation at $37^{\circ} \mathrm{C}$ in a $\mathrm{CO}_{2}$ humidified incubator cells were treated with several concentrations of PGPC or p-CA in triplicate well (test samples). Controls included in each experiment were as follow: 1) background control (medium only or various concentrations of PGPC or P-CA); this background values has to be subtracted from their corresponding values,

2) cells without treatment (low control) to measure the spontaneous release of LDH by cells, 3) maximum LDH release (high control) where Triton $\mathrm{x}-100$ (1\%) was used to disrupt the cytoplasmic membrane. At the end of incubation, $50 \mu \mathrm{L}$ of supernatant was taken, and LDH activity was assessed by measuring absorbance at $490 \mathrm{~nm}$ with a microplate reader.

Cytotoxicity (\%) was calculated as follow: (test samples - low control /high control - low Control) x 100.

\subsection{Apoptosis Assay}

U-2OS cells $\left(2 \times 10^{5}\right)$ were seeded in a 6-well plate. After $24 \mathrm{~h}$, cells were pre-incubated or not with $50 \mu \mathrm{M}$ N-benzyloxycarbonyl-Val-Ala-Asp-fluoromethylketone (z-VAD-fmk) for $1 \mathrm{~h}$. and then treated for $24 \mathrm{~h}$ with PGPC $(60 \mu \mathrm{g} / \mathrm{mL})$ and p-CA $(12500 \mu \mathrm{M})$. Cells were harvested into $15 \mathrm{~mL}$ Falcon tubes and washed twice with cold PBS. Subsequently, cell death was determined by APC-Annexin V and 7-amino-actinomycin D (7-AAD) staining with BioLegend's APC-Annexin V Apoptosis Detection Kit according to the manufacture's recommendations and analyzed by flow cytometry, on FACSCanto ${ }^{\mathrm{TM}}$ (BD Bioscienes), and FlowJo software version 10 (Tree Star).

\subsection{Measurement of free intracellular $\mathrm{Ca}^{2+}$ concentrations; $\left[\mathrm{Ca}^{2+}\right] \mathrm{i}$}

U-2OS cells were cultured on WillCo-dish wells with a glass bottom and loaded with Fura2/AM $(1 \mu \mathrm{M})$ for 60 minutes at $37^{\circ} \mathrm{C}$ in loading buffer that contained: $110 \mathrm{mM} \mathrm{NaCl} ; 5.4 \mathrm{mM}$ $\mathrm{KCl} ; 25 \mathrm{mM} \mathrm{NaHCO} 3 ; 0.8 \mathrm{mM} \mathrm{MgCl} 2 ; 0.4 \mathrm{mM} \mathrm{KH} 2 \mathrm{PO}_{4} ; 20 \mathrm{mM}$ HEPES-Na; $0.33 \mathrm{mM}$ $\mathrm{Na}_{2} \mathrm{HPO}_{4} ; 1.2 \mathrm{mM} \mathrm{CaCl}$, pH 7.4 as described by Dramane et al. (Dramane et al., 2012). The 
changes in intracellular $\mathrm{Ca}^{2+}\left(\mathrm{F}_{340} / \mathrm{F}_{380}\right)$ were monitored under a Nikon microscope (TiU) by using an S Fluor $40 \times$ oil immersion objective. The planes were taken at $\mathrm{z}$ intervals of $0.3 \mu \mathrm{m}$, and NIS-Elements software was used to deconvolve the images. The microscope was equipped with an EM-CCD (Lucas) camera for real-time recording of 16-bit digital images. The dual excitation fluorescence imaging system was used for studies of individual cells. The changes in intracellular $\mathrm{Ca}^{2+}$ were expressed as $\Delta$ ratio, which was calculated as the difference relative to the peak F340/F380 ratio. The data were summarized from the large number of individual cells (20-40 cells in a single run, with 3-9 identical experiments done in at least 3 cell preparations). For experiments conducted in the absence of external calcium $\left(0 \% \mathrm{Ca}^{2+}\right)$, $\mathrm{CaCl}_{2}$ was replaced by $1 \mathrm{mM}$ EGTA in the buffer. All test molecules were added in small volumes with no interruption in recordings.

\subsection{Cell cycle analysis by propidium iodide staining}

U-2OS cells were seeded in a 6-well plate $\left(2 \times 10^{5}\right.$ cells/well $)$. After $24 \mathrm{~h}$, cells were treated with PGPC $(60 \mu \mathrm{g} / \mathrm{mL})$ and p-CA $(12500 \mu \mathrm{M})$, which were combined or not with 5fluorouracil (5-FU, $2.5 \mu \mathrm{M}$ ) for another $24 \mathrm{~h}$. Cells were harvested and fixed in $70 \%$ ethanol for the overnight. Cells were washed twice, stained with propidium iodide, and treated with RNase-A for $1 \mathrm{~h}$ in darkness at $37{ }^{\circ} \mathrm{C}$. Cells were assessed for their DNA contents by cytometry on FACS Canto, and data were analyzed using ModFit LT software version 3.3.11.

\subsection{RT-PCR quantification assay}

Total RNA was prepared using trizol reagent (Invitrogen Life Technologies). $1 \mu \mathrm{g}$ of total RNA was reverse transcribed with superscript II RNAse H-reverse transcriptase using oligo (dT) according to the manufacturer's instructions (Invitrogen Life Technologies, France). 
172 Real-time PCR was performed using the icycler iQ ${ }^{\mathrm{TM}}$ Real Time Detection system (Applied). 173 Amplification reactions were performed using SYBR Green I detection 7500 Fast Real-Time 174 PCR System (Applied Biosystems) with the following primers as previously described 175 (Minville-Walz et al., 2010) : CHOP: sense 5'-ACA CAG ATG AAA ATG GGG GTA CCT176 3' and antisense 5'-AGA AGC AGG ATC AAG AGT GGT CCT-3'; BAK sense 5'-TTA 177 CCG CCA TCA GCA GGA ACA-3' and antisense: 5'-ATG GGA CCA TTG CCC AAG TTC-3'; BAX sense 5'-ACC AGC TCT GAG CAG ATC ATG G-3' and antisense: 5'-CCT CTT CCA GAT GGT GAG CGA-3'; Bcl-2 sense 5'-GTC ATG TCT GTC GAG AGC GT-3' and antisense 5'-ACA GTT CCA CCA AGG CAT CC-3' ; XBP1 sense 5'-AAA CAG AGT AGC AGC TCA GAC TGC-3' and antisense 5'-TCC TTC TGG GTA GAC CTC TGG GAG3'; $\beta$-actin: 5'-CTG GTG CCT GGG GCG-3' and 5'-AGC CTC GCC TTT GCC GA-3'. CHOP, BAK, BAX, Bcl-2, and XBP1 expressions were normalized to $\beta$-actin and calculated using the $2^{-\Delta \Delta \mathrm{Ct}}$ method.

\subsection{Western Blot Analysis}

U-2OS cells $\left(2 \times 10^{6}\right)$ were seeded in Petri dishes and treated with two concentrations of PGPC (60 and $75 \mu \mathrm{g} / \mathrm{mL}$ ) for $24 \mathrm{~h}$. Cells were lysed in $200 \mu \mathrm{L}$ RIPA lysis buffer (Thermo Fisher Scientific Inc., Rockford, IL, USA). Proteins concentration was determined by Bicinchoninic acid (BCA) Assay Kit (Sigma-Aldrich, USA). Subsequently, proteins $(80 \mu \mathrm{g})$ were separated on a $12 \%$ polyacrylamide gel and electroblotted on a PVDF membrane. The membrane was saturated during $1 \mathrm{~h}$ in $5 \%$ bovine serum albumin (w/v) in Tris Buffered

192 Saline containing $0.1 \%$ Tween-20 (TBS-T) and then incubated with primary antibodies: antiphospho-AKT (Ser473), anti-phospho-AKT (Thr308), anti-AKT, anti-Caspase-8, anticaspase-9, anti-cleaved PARP, anti-cdc2, anti-CDK2, anti-cyclin A, anti-cyclin E, anti-c-Src, anti-phospho-p70 S6K, anti-p70 S6K, anti-phospho-p44/42 MAPK, anti-p44/42 MAPK, antiphospho-p38 MAPK, anti-p38 MAPK, anti-phospho-SAPK/JNK, anti- SAPK/JNK, anti- 
phospho-p53, anti-p53, and anti-phospho-STAT3 at $4{ }^{\circ} \mathrm{C}$ overnight. $\beta$-actin was used as an internal control. Primary antibodies were then detected either with anti-rabbit IgG, HRPlinked antibody or anti-mouse IgG2b-HRP secondary antibody. Blots were visualized using an ECL Kit (Merck Millipore) on Bio-Rad Chemi-Doc XRS ${ }^{+}$system. Densitometric analysis was performed on Bio-Rad Image Lab Software (version 4.1).

\subsection{Statistical Analysis}

Results were expressed as mean \pm SD (standard error deviation) for a given number of experiments (n). Data were analyzed by using Statistica (4.1 version, Statsoft, Paris, France). The significance of differences between mean values was determined by one-way ANOVA, followed by Fisher's least-significant-difference (LSD) test. Differences with $p<0.05$ were considered to be significant.

\section{Results}

\subsection{Cell Viability}

Trypan blue exclusion test showed that PGPC and p-CA significantly reduced U-2OS cell viability in a dose dependent-manner (Fig.1). IC $_{50}$ was estimated to be $80 \mu \mathrm{g} / \mathrm{mL}$ for PGPC and around $17000 \mu \mathrm{M}$ for $\mathrm{p}$-CA. Moreover, $\mathrm{p}$-CA at $25000 \mu \mathrm{M}$ induced more than $80 \%$ of U$2 \mathrm{OS}$ cell death. However, $100 \mu \mathrm{g} / \mathrm{mL}$ concentration of PGPC was required to achieve $75 \%$ of U-2OS cell death. The lactate dehydrogenase (LDH) assessment demonstrated that both pCoumaric acid and PGPC induced U-2OS cell death in a dose-dependent manner as these treatments increased the membrane permeability, evidenced by high LDH levels, when compared with untreated cells (insert). We therefore chose less toxic doses of PGPC (i.e. 60 $\mu \mathrm{g} / \mathrm{mL}$ and $75 \mu \mathrm{g} / \mathrm{mL})$ and $\mathrm{p}-\mathrm{CA}(12500 \mu \mathrm{M})$ for all the subsequent experiments. 


\subsection{Apoptosis Assay}

221 We used Annexin-V/7-AAD staining to investigate the cell death induced by PGPC and p-

222 CA. Interestingly, our findings demonstrate that PGPC and to a lesser extent p-CA induced

223

224

225 cell death mainly via apoptosis as shown by a significant decrease in cell death when cells were co-treated with z-VAD-fmk, a pan-caspase inhibitor (Fig. 2).

We further explored the involvement of calcium in the apoptosis induced by PGPG. In this regard, U-2OS cells were treated with PGPC $(60 \mu \mathrm{g} / \mathrm{mL})$ in presence of BAPTA-AM, a cytoplasmic calcium chelator, $(5 \mu \mathrm{M})$ or ruthenium red $(\mathrm{RuR})$, an inhibitor of mitochondrial $\mathrm{Ca}^{2+}$ uptake, $(5 \mu \mathrm{M})$.

As expected, we observed that co-treatment with BAPTA-AM impaired U-2OS cell death induced by PGPC, but surprisingly, RuR potentiated PGPC-induced cell death as $64 \%$ of cells were Annexin V positive (Fig. 3).

Since the inhibition of mitochondrial $\mathrm{Ca}^{2+}$ uniporter exacerbated PGPC-induced cell death, in the subsequent experiment, cells, pre-incubated with RuR, were co-treated with z-VAD-fmk or with autophagy inhibitors, 3-Methyladenine (3-MA) and chloroquine (CQ).

Again, z-VAD-fmk attenuated cell death caused by co-treatment with RuR, but 3-MA and CQ failed to impair the already observed cell death (Fig. 3).

\subsection{Detection of Apoptosis-Related Proteins}

Fig. 4A shows that PGPC treatment induced p53 phosphorylation in U-2OS cells. Thus, PGPC induced caspase- 8 and caspase-9, which is an essential downstream component of p53, activation. Indeed, PGPC triggered pro-caspase- 8 and pro-caspase- 9 cleavage into their active fragments. Furthermore, PGPC induced PARP cleavage, a downstream substrate of both caspase- 8 and caspase- 9 . 
The activation of pro-apoptotic proteins (XBP1, BAX / BAK, and CHOP) and the inactivation of the anti-apoptotic protein Blc-2 play key roles in endoplasmic reticulum (ER)-dependent apoptosis. Our results showed that PGPC treatment increased transcription of XBP1, BAX / BAK, and CHOP mRNA expression and decreased Bcl-2 mRNA expression in U-2OS cancer cells (Fig. 4B).

\subsection{Effect of PGPC on intracellular $\mathrm{Ca}^{2+}$ in $\mathrm{U}-2 \mathrm{OS}$ cells}

PGPC induced a sustained increase in $\left[\mathrm{Ca}^{2+}\right] \mathrm{i}$ in $\mathrm{U}-2 \mathrm{OS}$ cells. In order to assess the origin of $\mathrm{Ca}^{2+}$ mobilized by phenolic compounds, we conducted experiments in the absence $\left(0 \% \mathrm{Ca}^{2+}\right)$ and presence $\left(100 \% \mathrm{Ca}^{2+}\right)$ of $\mathrm{Ca}^{2+}$ in the extracellular medium. Fig. 5 shows that the PGPC induced significant increases in $\left[\mathrm{Ca}^{2+}\right] \mathrm{i}$ in $0 \%$ and in $100 \% \mathrm{Ca}^{2+}$ medium, suggesting that PGPC induced a $\mathrm{Ca}^{2+}$ influx from extracellular medium and also mobilized calcium release from intracellular stores.

\subsection{Effect of PGPC on AKT/MAPK pathways in U-2OS cells}

We assessed the effect of PGPC on AKT activation in U-2OS osteosarcoma cells. PGPC treatment resulted in a significant decrease of AKT phosphorylation in Thr308 and ser 473 residues which were associated with proto-oncogene tyrosine-protein kinase (c-SRC), an AKT upstream effector, decrease. Regarding AKT downstream substrates, PGPC treatment negatively regulated P70 S6K and STAT3 phosphorylation (Fig. 6A). In addition to a significant increase in p38 MAPK phosphorylation, SAPK/JNK was also phosphorylated in response to PGPC treatment, however, PGPC did not affect ERK1/2 MAPK activation (Fig. 6B). 


\subsection{Cell cycle distribution analysis}

268

269

270

271

272

273

274

275

276

277

278

We further analyzed the effect of PGPC on cell cycle progression by using propidium iodide staining. We observed that PGPC $(60 \mu \mathrm{g} / \mathrm{mL})$ and to a greater extent p-CA $(12500 \mu \mathrm{M})$ induced cell cycle arrest of U-2OS cells in the S phase (Fig. 7A). As shown in Fig. 7B, the repartition of cell populations between different phases of cell cycle in U-2OS was as follow: $49.53 \%$ in $\mathrm{G} 1,28.37 \%$ in $\mathrm{S}$ and $22.09 \%$ in $\mathrm{G} 2 / \mathrm{M}$. PGPC $(60 \mu \mathrm{g} / \mathrm{mL})$ treatment increased $\mathrm{S}$ population to $41.37 \%$ and p-CA to $42.18 \%$. A small concentration of 5-FU, $2.5 \mu \mathrm{M}$, induced cell cycle arrest in G1 phase. However 5-FUco-treated with PGPC or p-CA induced cell cycle arrest in S phase with a significant decrease of G2/M phase.

\subsection{Cyclins and CDKs expression analysis}

Western blot analyses shows that PGPC induced a significant decrease in human cyclindependent kinase-2 (CDK2) associated with cyclin E increase when compared to untreated cells. However, no effects were noticed on cyclin-dependent kinase cdc2/CDK1, and cyclinA expression in U-2OS cells (Fig. 7C).

\section{Discussion}

Dietary polyphenols-rich food intake has been correlated with low cancer incidences. Moreover, several phenolic compounds have been proposed as potential anticancer agents alone or as adjuvants with classical chemotherapy (León-González, Auger, \& Schini-Kerth, 2015). Dietary polyphenols exert their anti-carcinogenic activity by several mechanisms. Furthermore, depending on tissue or cell type, the effects of polyphenols could differ on whether they are used at high or low doses (Ramos, 2008). 
The aim of this study was to investigate the effects of Pennisetum glaucum phenolic compounds (PGPC) on human osteosarcoma U-2OS cells, which express wild type p53 (Grossel, Baker, \& Hinds, 1999), in vitro.

We have shown previously through HPLC analysis that that p-coumaric acid and ferulic acid are the most abundant phenolic compounds in Pennisetum glaucum grains (Nani et al., 2015). In addition, gallic acid, chlorogenic acid, caffeic acid, quercetin, and apigenin were detected in these grains (Nani et al., 2015; Shahidi \& Chandrasekara, 2013). In the present study, our results indicate that PGPC and, to a lesser extent, p-CA induced U-2OS cell death, in a dose dependent manner, with an $\mathrm{IC}_{50}$ of $80 \mu \mathrm{g} / \mathrm{mL}$ and $17000 \mu \mathrm{M}$, respectively. Next, we have investigated the type of the observed cell death. PGPC and p-CA increased LDH release from U-2OS cells suggesting that U-2OS cells underwent an apoptosis in response to PGPC and pCA treatments. Interestingly, Annexin V/7-AAD staining revealed that PGPC and p-CA induced cell death mainly via apoptosis as evidenced by a significant impairment of cell death when co-treated with z-VAD-fmk. The apoptotic effects of food-derived polyphenols and purified phenolic compounds have been extensively researched (Darvin et al., 2015; Jaganathan, Supriyanto, \& Mandal, 2013; Moore et al., 2016; Mouria et al., 2002). Polyphenols obtained from sorghum, a principal cereal food used besides millet in many countries, induced apoptosis in HCT-116 and HCT-15 colon cancer cells (Darvin et al., 2015). Thus, p-CA has been reported to exert apoptotic effects in HCT-15 colon cancer cells (Jaganathan et al., 2013). Other study reported that ferulic acid, the second most abundant phenolic acid in Pennisetum glaucum, promoted apoptosis in osteosarcoma cells ( $\mathrm{T}$ et al., 2016).

Since calcium was shown to play a crucial role in apoptosis (Nicotera \& Orrenius, 1998), in subsequent experiment, U-2OS cells were pre-incubated with either BAPTA-AM $(5 \mu \mathrm{M})$ or RuR $(5 \mu \mathrm{M})$ for $1 \mathrm{~h}$, and then treated with PGPC for $24 \mathrm{~h}$. BAPTA-AM co-treatment 
significantly curtailed PGPC-induced cell death, but RuR potentiated PGPC-induced cell death. Apoptosis is the major type of cell death that occurs in response to irreparable DNA damage. Conversely, conventional apoptosis blockage can promote other programmed cell death pathways, i.e. autophagy and necroptosis, although the boundary between apoptosis and autophagy has never been completely clear (Goodall et al., 2016; Lockshin \& Zakeri, 2004; Ouyang et al., 2012).

To further investigate whether there was a switch to autophagy programmed cell death when mitochondrial calcium uptake was inhibited, cells were pre-incubated with $\mathrm{RuR}(5 \mu \mathrm{M})$, and then co-treated with z-VAD-fmk $(50 \mu \mathrm{M})$ or 3-MA $(5 \mathrm{mM})$ or CQ $(50 \mu \mathrm{M})$. Results showed that $\mathrm{z}$-VAD-fmk impaired the cell death induced by RuR-co-treatment. In contrast, we did not notice any significant effect of 3-MA and CQ on the cell death induced by RuR-co-treatment. Taken together, these findings suggest that the inhibition of mitochondrial-dependent apoptosis might exacerbate an alternative mitochondrial-independent apoptosis pathway rather than induce autophagy.

The extrinsic, or death-receptor pathway, and intrinsic, or mitochondrial pathway are the most described pathways of the apoptosis machinery (Eum \& Lee, 2011). In most human cancers, the p53 -tumor suppressor- protein or pathway is mutated or inactivated (Vogelstein, Lane, \& Levine, 2000). We and others have shown that p53 can mediate caspase-dependent apoptosis, and many stimuli, including polyphenols, trigger apoptosis through the activation of initiator caspases (caspase-8 and caspase-9) (Ghanemi et al., 2017; Hajiaghaalipour, Kanthimathi, Sanusi, \& Rajarajeswaran, 2015; Torkin, Lavoie, Kaplan, \& Yeger, 2005). In the current study, western blot analysis showed that PGPC treatment enhanced p53 expression and activation associated with both caspase- 8 and caspase- 9 cleavage into their active 
substrates. Indeed, PARP, a downstream substrate of caspase-8 and caspase-9, was also cleaved in response to PGPC treatment.

A new intrinsic pathway of apoptosis involving the endoplasmic reticulum (ER) stress has been described (Li, Guo, Tang, Jiang, \& Chen, 2014; Rodriguez, Rojas-rivera, \& Hetz, 2011). In response to ER stress, inositol-requiring enzyme 1 (IRE1) mediates a pathway known as 342 unfolded protein response (UPR) in which gene expression is altered (Li et al., 2014). 343 However, severe ER stress can lead to programmed cell death. Indeed, ER stress can activate 344 the pro-apoptotic Jun N-terminal Kinase (JNK) through IRE1-dependent tumor necrosis factor (TNF)-Receptor Associated Factor (TRAF2) recruitment (Deegan, Saveljeva, Gorman, \& Samali, 2013). The latter could abolish the mTOR-mediated oncogenic pathway (Ding et al., 2007). Moreover, alteration in calcium homeostasis, splicing of $\mathrm{X}$ box-bindingprotein 1 (XBP1) mRNA, and increased CHOP expression are usually described in ER stress-mediated apoptosis (Rodriguez et al., 2011). Thus, p38 MAPK has been reported to downregulate Bcl-2 survival protein via CHOP, a highly stress-inducible gene, activation (Szegezdi, Logue, Gorman, \& Samali, 2006). We have previously demonstrated that PEOL induced intrinsic apoptosis mediated by ROS generation, increase of mRNA CHOP expression and phosphorylation of eukaryotic initiation factor 2alpha (eIF2 $\alpha$ ) in HCT 116 and HCT8 human 354 colorectal cancer cells (Zeriouh et al., 2017). In the present study, PGPC treatment increased mRNA expression of Bax, XBP1, and CHOP in U-2OS osteosarcoma cells, whereas, Bcl-2 mRNA expression has decreased in response to PGPC treatment. Consistent with our observations, resveratrol induced cell cycle arrest via UPR in chronic myelogenous leukemia 358 cells (K562). In addition to eIF2alpha phosphorylation, transcriptional induction of CHOP 359 and ER stress-specific XBP1 splicing were observed when K562 cells were treated with resveratrol (Liu et al., 2010). Overall, these findings suggest that PGPC induced both caspasedependent and ER stress-mediated apoptosis in U-2OS osteosarcoma cells. 
Increase in cytoplasmic (or intracellular) calcium, $\left[\mathrm{Ca}^{2+}\right] \mathrm{i}$, is described to accompany or to initiate apoptosis (Nicotera \& Orrenius, 1998). We examined the action of PGPC on the increase in $\left[\mathrm{Ca}^{2+}\right] \mathrm{i}$ in U-2OS cells. In the presence of $100 \% \mathrm{Ca}^{2+}$ PGPC induced high increases in $\left[\mathrm{Ca}^{2+}\right] \mathrm{i}$, suggesting that $\mathrm{Ca}^{2+}$ influx plays a major role in $\left[\mathrm{Ca}^{2+}\right] \mathrm{i}$ increase evoked by this extract. In contrast, in calcium-free medium $\left(0 \% \mathrm{Ca}^{2+}\right)$, we also noticed increases in $\left[\mathrm{Ca}^{2+}\right] \mathrm{i}$, suggesting that PGPC mobilize calcium also from internal stores. The kinetic study of PGPC-induced $\mathrm{Ca}^{2+}$ mobilization showed that these compounds produced a sustained increase in $\left[\mathrm{Ca}^{2+}\right]$ i. We have previously demonstrated such increase in $\left[\mathrm{Ca}^{2+}\right] \mathrm{i}$ associated with antiproliferative effect of polyphenols (Aires et al., 2004; Nani et al., 2015; Zeriouh et al., 2017).

AKT signaling is one of the most common aberrant pathways in cancer cells. AKT has emerged as a primary downstream mediator of PI3K signaling, and multiple downstream mediators of AKT, including mammalian target of rapamycin (mTOR) and transcription factor STAT3 have been suggested (Nishimoto, 2000; Nitulescu et al., 2016; Riemenschneider et al., 2006). In fact, through up-regulation of mTOR signaling with direct inhibition of pro-apoptotic proteins, AKT, enhances proliferation and inhibits apoptosis of tumor cells (Fruman \& Rommel, 2014; Osaki, Oshimura, \& Ito, 2004). Indeed, it has been reported that AKT could promote p53 tumor suppressor inactivation and degradation (Downward, 2004). Consequently, AKT inhibitors have been gaining ground as anticancer agents nearly two decades ago (Nitulescu et al., 2016). It has been shown that PI3K/AKT signal transduction pathway and STAT3 activation can be triggered by Src (Díaz-Montero, Wygant, \& McIntyre, 2006; Fossey et al., 2009; Hingorani, Zhang, Gorlick, \& Kolb, 2009). This latter is a non-receptor tyrosine kinase that is activated in multiple cancers, including osteosarcoma (Díaz-Montero et al., 2006). PI3K/AKT signaling promotes the proliferation and migration of osteosarcoma cells (Xu, Wang, \& Xu, 2013). One report indicates that Src 
activation resulted in an increase of AKT phosphorylation at Ser473 in human osteosarcoma SAOSp cells (Díaz-Montero et al., 2006). A recent study has focused on the inhibition of Src and mTOR kinases as a potential therapy of osteosarcoma (Botter, Neri, \& Fuchs, 2014). Moreover, it has been demonstrated that STAT3, which is strongly associated with the prognosis of osteosarcoma, was phosphorylated in a subset of human osteosarcoma tissues and cell lines (Fossey et al., 2009; Zhou et al., 2014). In our study, interestingly, PGPC treatment curtailed c-SRC expression, AKT phosphorylation (at Ser 473 and Thr 308), and STAT3 phosphorylation, suggesting that PGPC exerted an anti-proliferative activity via the downregulation of c-SRC/AKT/STAT3 pathway in U-2OS osteosarcoma cells. In line with our results, many researches have shown that polyphenols can regulate both upstream and downstream effectors of AKT (Darvin et al., 2015; Wang et al., 2016; Yu et al., 2001). Ferulic acid, the second major phenolic acid in Pennisetum glaucum, was shown to attenuate AKT phosphorylation in osteosarcoma cells (Wang et al., 2016). Sorghum polyphenols dosedependently decreased STAT3 phosphorylation in HCT-116 and HCT-15 colon cancer cells (Darvin et al., 2015). Thus, resveratrol diminished c-Src activity in Hela cells (Yu et al., 2001).

AKT activation is thought, also, to abolish SAPK/JNK and p38 MAPK (also referred as p38), which have been considered as putative tumor suppressors, activation in response to various stresses (Jiang et al., 2017; Su et al., 2014; Wagner \& Nebreda, 2009). p38, can phosphorylate p53 in several residues, including Ser46, which are all involved in the onset of apoptosis (Huang, Ma, Maxiner, Sun, \& Dong, 1999; Perfettini et al., 2005; Zechner, Thuerauf, Hanford, McDonough, \& Glembotski, 1997). We, therefore, wanted to assess the effects of PGPC on MAPKs pathways. Interestingly, PGPC treatment significantly increased SAPK/JNK and p38 but not ERK activity. This is consistent with results demonstrating the anticancer proprieties of polyphenols, such as quercetin and resveratrol, through the 
modulation of SAPK/JNK and p38 activity (Kim, Kim, Choi, \& Son, 2016; She, Bode, Ma, Chen, \& Dong, 2001). Quercetin sensitized pancreatic cancer cells to tumor-necrosis-factor related apoptosis inducing ligand (TRAIL)-induced apoptosis through SAPK/JNK activation (Kim et al., 2016). Reseveratrol induced p38-mediated phosphorylation of p53 in JB6 Cl 41 cells (She et al., 2001).

P70 S6K, one of the crucial targets of mTOR, can promote cell proliferation, in part by inactivation of the death promoter Bad (Harada, Andersen, Mann, Terada, \& Korsmeyer, 2001). Therefore, we further explored the effect of PGPC on P70 S6K. Interestingly, PGPC seemed effective in inhibition of p70S6K activation, suggesting that PGPC treatment abolished AKT/mTOR/p70S6K pathway in U-2OS osteosarcoma cells. Moreover, previous studies have revealed that polyphenols suppressed cell proliferation through the inhibition of AKT/mTOR/p70S6K (Castillo-Pichardo \& Dharmawardhane, 2012; Moore et al., 2016).

Cancer cells are known for their hallmark ability to replicate indefinitely and escape programmed cell death (Pentimalli \& Giordano, 2009). It has been reported that proteolysis of p53 and cyclin dependent kinase inhibitors (CKIs), such as p21 and p27, were correlated with overexpression of cyclins and loss of CKIs expression in many cancer cells (Rastogi \& Mishra, 2012). Indeed, one report suggested that p53 is required for maintenance of S-phase arrest (Giono \& Manfredi, 2006). Therefore, challenging efforts aim to conceive therapeutic approaches based on cyclin-dependent kinases(CDKs) inhibition (Malumbres \& Barbacid, 2009). In the current study, we showed that both PGPC and p-CA induced cell cycle arrest in S phase, while 5-FU at low dose $(2.5 \mu \mathrm{M})$ blocked cell progression in G1 phase. However, 5FU combination with PGPC or p-CA caused U-2OS cells accumulation in S phase, suggesting that PGPC and p-CA do not share common targets with 5-FU. Regarding cyclins and CDKs involved in S phase entry and progression, CDK2 expression was significantly decreased, and 
cyclin E was significantly increased in response to PGPC treatment. Nonetheless, PGPC did not seem to affect cdc2/CDK1 and cyclin A expression.

Previous studies have demonstrated that polyphenols caused cells accumulation in S phase by decreasing CDK2 and/or increasing cyclin E expression (Chou et al., 2010; Larrosa, TomàsBarberàn, \& Espín, 2003). Another study highlighted the inhibitory effect of ferulic acid on CDK2 expression in osteosarcoma cells (Wang et al., 2016).

\section{Conclusion}

From our findings, we can state that PGPC downregulates AKT upstream and downstream effectors which are associated with p38 and SAPK/JNK up-regulation, and increased $\left[\mathrm{Ca}^{2+}\right] \mathrm{i}$, resulting in cell cycle arrest and caspase-dependent apoptosis in osteosarcoma U-2OS cells. Overall, this study encourages the exploration of pearl millet polyphenols as a promising candidate for osteosarcoma prevention and treatment. Nonetheless, anti-tumor effects in animal models remain to be investigated.

\section{Declare of interest}

The authors have declared no conflicts of interest.

\section{Acknowledgments}

The study was supported, in part, by Labex LipSTIC INSERM U1231 University of Burgundy, France and a bilateral Franco-Algerian collaborative project “Tassili” (grant number $30850 \mathrm{QG})$. The funders had no role in study design, data collection and analysis, decision to publish, or preparation of the manuscript. TM work is supported in part by the NCI Core Center grant P30 CA008748, Swim Across America, Ludwig Institute for Cancer Research, Parker Institute for Cancer Immunotherapy and Breast Cancer Research Foundation.

\section{References}

Aires, V., Adote, S., Hichami, A., Moutairou, K., Boustani, E. S., \& Khan, N. A. (2004). Modulation of intracellular calcium concentrations and $\mathrm{T}$ cell activation by prickly pear 
polyphenols. Mol Cell Biochem, 260(1-2), 103-110. Retrieved from http://www.ncbi.nlm.nih.gov/pubmed/15228091

Allison, D. C., Carney, S. C., Ahlmann, E. R., Hendifar, A., Chawla, S., Fedenko, A., Angeles, C., \& Menendez, L. R. (2012). A meta-analysis of osteosarcoma outcomes in the modern medical era. Sarcoma, 2012. http://doi.org/10.1155/2012/704872

Bakhshi, S., \& Radhakrishnan, V. (2010). Prognostic markers in osteosarcoma. Expert Review of Anticancer Therapy, 10(2), 271-287.

Banerjee, N., Kim, H., Krenek, K., Talcott, S. T., \& Mertens-Talcott, S. U. (2015). Mango polyphenolics suppressed tumor growth in breast cancer xenografts in mice: role of the PI3K/AKT pathway and associated microRNAs. Nutrition Research, 35(8), 744-751. http://doi.org/10.1016/j.nutres.2015.06.002

Botter, S. M., Neri, D., \& Fuchs, B. (2014). Recent advances in osteosarcoma. Current Opinion in Pharmacology, 16, 15-23.

Castillo-Pichardo, L., \& Dharmawardhane, S. F. (2012). Grape Polyphenols Inhibit Akt/Mammalian Target of Rapamycin Signaling and Potentiate the Effects of Gefitinib in Breast Cancer. Nutrition and Cancer, 64(7), 1058-1069. http://doi.org/10.1080/01635581.2012.716898

Cho, I. J., Chang, H. J., Lee, K. E., Won, H. S., Choi, M. Y., Nam, E. M., Mun, Y-C., Lee, S. N., \& Seong, C.-M. (2009). A case of Wernicke's encephalopathy following fluorouracil-based chemotherapy. Journal of Korean Medical Science, 24(4), 747-750.

Chou, C.-C., Yang, J.-S., Lu, H.-F., Ip, S.-W., Lo, C., Wu, C.-C., Lin, J-P., Tang, N-Y., Chung, J-G., Chou, M-J., Teng, Y-H., \& Chen, D.-R. (2010). Quercetin-mediated cell cycle arrest and apoptosis involving activation of a caspase cascade through the mitochondrial pathway in human breast cancer MCF-7 cells. Archives of Pharmacal Research, 33(8), 1181-1191. http://doi.org/10.1007/s12272-010-0808-y 
Darvin, P., Joung, Y. H., Nipin, S. P., Kang, D. Y., Byun, H. J., Hwang, D. Y., Cho, K. H., Park, K. D., Lee, H. K., \& Yang, Y. M. (2015). Sorghum polyphenol suppresses the growth as well as metastasis of colon cancer xenografts through co-targeting jak2/STAT3 and PI3K/Akt/mTOR pathways. Journal of Functional Foods, 15, 193-206. http://doi.org/10.1016/j.jff.2015.03.020

Deegan, S., Saveljeva, S., Gorman, A. M., \& Samali, A. (2013). Stress-induced selfcannibalism: on the regulation of autophagy by endoplasmic reticulum stress. Cellular and Molecular Life Sciences, 70(14), 2425-2441.

Díaz-Montero, C. M., Wygant, J. N., \& McIntyre, B. W. (2006). PI3-K/Akt-mediated anoikis resistance of human osteosarcoma cells requires Src activation. European Journal of Cancer, 42(10), 1491-1500. http://doi.org/10.1016/j.ejca.2006.03.007

Ding, W.-X., Ni, H.-M., Gao, W., Yoshimori, T., Stolz, D. B., Ron, D., \& Yin, X.-M. (2007). Linking of autophagy to ubiquitin-proteasome system is important for the regulation of endoplasmic reticulum stress and cell viability. The American Journal of Pathology, 171(2), 513-524.

Downward, J. (2004). PI 3-kinase, Akt and cell survival. Seminars in Cell and Developmental Biology, 15(2), 177-182. http://doi.org/10.1016/j.semcdb.2004.01.002

Dramane, G., Abdoul-Azize, S., Hichami, A., Vögtle, T., Akpona, S., Chouabe, C., Sadou, H., Nieswandt, B., Besnard, P., \& Khan, N. A. (2012). STIM1 regulates calcium signaling in taste bud cells and preference for fat in mice. Journal of Clinical Investigation, 122(6), 2267-2282. http://doi.org/10.1172/JCI59953

Eum, K. H., \& Lee, M. (2011). Crosstalk between autophagy and apoptosis in the regulation of paclitaxel-induced cell death in v-Ha-ras-transformed fibroblasts. Molecular and Cellular Biochemistry, 348(1-2), 61-68. http://doi.org/10.1007/s11010-010-0638-8

Folin, O., \& Ciocalteu, V. (1927). On tyrosine and tryptophane determinations in proteins. $J$. 
Biol. Chem, 73(2), 627-650.

517 Fossey, S. L., Liao, A. T., McCleese, J. K., Bear, M. D., Lin, J., Li, P.-K., Kisseberth, W. C., \& London, C. A. (2009). Characterization of STAT3 activation and expression in canine and human osteosarcoma. BMC Cancer, 9, 81. http://doi.org/10.1186/1471-2407-9-81

Fruman, D. A., \& Rommel, C. (2014). PI3K and cancer: lessons, challenges and opportunities. Nature Reviews Drug Discovery, 13(2), 140.

Ghanemi, F. Z., Belarbi, M., Fluckiger, A., Nani, A., Dumont, A., De Rosny, Aboura, I., Khan, A. S., Murtaza, B., Benammar, C., Lahfa, B. F., Patoli, D., Delmas, D., Rébé, C., Apetoh, L., Khan, N. A., Ghringhelli, F., Rialland, M., \& Hichami, A. (2017). Carob leaf polyphenols trigger intrinsic apoptotic pathway and induce cell cycle arrest in colon cancer cells. Journal of Functional Foods, 33, 112-121.

Giono, L. E., \& Manfredi, J. J. (2006). The p53 tumor suppressor participates in multiple cell cycle checkpoints. Journal of Cellular Physiology, 209(1), 13-20.

Goodall, M. L., Fitzwalter, B. E., Zahedi, S., Wu, M., Rodriguez, D., Mulcahy-Levy, J. M., Green, D. R., Morgan, M., Cramer, S. D. \& Thorburn, A. (2016). The Autophagy Machinery Controls Cell Death Switching between Apoptosis and Necroptosis. Developmental Cell, 37(4), 337-349. http://doi.org/10.1016/j.devcel.2016.04.018

Grossel, M. J., Baker, G. L., \& Hinds, P. W. (1999). Cdk6 can shorten G1 phase dependent upon the N-terminal INK4 interaction domain. Journal of Biological Chemistry, 274(42), 29960-29967.

Hajiaghaalipour, F., Kanthimathi, M. S., Sanusi, J., \& Rajarajeswaran, J. (2015). White tea (Camellia sinensis) inhibits proliferation of the colon cancer cell line, HT-29, activates caspases and protects DNA of normal cells against oxidative damage. Food Chemistry, 169, 401-410. http://doi.org/10.1016/j.foodchem.2014.07.005

Hanahan, D., \& Weinberg, R. A. (2011). Hallmarks of cancer: the next generation. Cell, 
Harada, H., Andersen, J. S., Mann, M., Terada, N., \& Korsmeyer, S. J. (2001). p70S6 kinase signals cell survival as well as growth, inactivating the pro-apoptotic molecule BAD. Proceedings of the National Academy of Sciences of the United States of America, 98(17), 9666-70. http://doi.org/10.1073/pnas.171301998

Hingorani, P., Zhang, W., Gorlick, R., \& Kolb, E. A. (2009). Inhibition of Src phosphorylation alters metastatic potential of osteosarcoma in vitro but not in vivo. Clinical Cancer Research, 15(10), 3416-3422. http://doi.org/10.1158/1078-0432.CCR08-1657

550

Huang, C., Ma, W. Y., Maxiner, A., Sun, Y., \& Dong, Z. (1999). p38 kinase mediates UVinduced phosphorylation of p53 protein at serine 389. Journal of Biological Chemistry, 274(18), 12229-12235. http://doi.org/10.1074/jbc.274.18.12229

Jaganathan, S. K., Supriyanto, E., \& Mandal, M. (2013). Events associated with apoptotic effect of $\mathrm{p}$-Coumaric acid in HCT-15 colon cancer cells. World Journal of Gastroenterology, 19(43), 7726-7734. http://doi.org/10.3748/wjg.v19.i43.7726

Jiang, X., Zhu, X., Xu, H., Zhao, Z., Li, S., Li, S., Cai, J-H., \& Cao, J. (2017). Diallyl trisulfide suppresses tumor growth through the attenuation of Nrf2/Akt and activation of p38/JNK and potentiates cisplatin efficacy in gastric cancer treatment. Acta Pharmacologica Sinica, 38(7), 1048.

Kim, J. H., Kim, M. J., Choi, K.-C., \& Son, J. (2016). Quercetin sensitizes pancreatic cancer cells to TRAIL-induced apoptosis through JNK-mediated cFLIP turnover. The International Journal of Biochemistry \& Cell Biology, 78, 327-334. http://doi.org/10.1016/j.biocel.2016.07.033

Larrosa, M., Tomàs-Barberàn, F. A., \& Espín, J. C. (2003). Grape polyphenol resveratrol and the related molecule 4-hydroxystilbene induce growth inhibition, apoptosis, S-phase 
arrest, and upregulation of cyclins A, E, and B1 in human SK-Mel-28 melanoma cells. Journal of Agricultural and Food Chemistry, 51(16), 4576-4584. http://doi.org/10.1021/jf030073c

León-González, A. J., Auger, C., \& Schini-Kerth, V. B. (2015). Pro-oxidant activity of polyphenols and its implication on cancer chemoprevention and chemotherapy. Biochemical Pharmacology, 98(3), 371-380. http://doi.org/10.1016/j.bcp.2015.07.017

Li, Y., Guo, Y., Tang, J., Jiang, J., \& Chen, Z. (2014). New insights into the roles of CHOPinduced apoptosis in ER stress Structure and Properties of C / EBP Homologous Protein Roles of CHOP in ER Stress-Mediated Apoptosis. Acta Biochimica et Biophysica Sinica, 46(8), 629-640. http://doi.org/10.1093/abbs/gmu048.Review

Linke, S. P., Clarkin, K. C., Di Leonardo, A., Tsou, A., \& Wahl, G. M. (1996). A reversible, p53-dependent Go/G1 cell cycle arrest induced by ribonucleotide deplenon in the absence of detectable DNA damage. Genes \& Development, 10, 934-937. http://doi.org/10.1101/gad.10.8.934

Liu, B.-Q., Gao, Y.-Y., Niu, X.-F., Xie, J.-S., Meng, X., Guan, Y., \& Wang, H.-Q. (2010). Implication of unfolded protein response in resveratrol-induced inhibition of K562 cell proliferation. Biochemical and Biophysical Research Communications, 391(1), 778-782.

Lockshin, R. A., \& Zakeri, Z. (2004). Apoptosis, autophagy, and more. International Journal of Biochemistry and Cell Biology, 36(12), 2405-2419. http://doi.org/10.1016/j.biocel.2004.04.011

Luetke, A., Meyers, P. A., Lewis, I., \& Juergens, H. (2014). Osteosarcoma treatment - Where do we stand? A state of the art review. Cancer Treatment Reviews, 40(4), 523-532. http://doi.org/10.1016/j.ctrv.2013.11.006

Malumbres, M., \& Barbacid, M. (2009). Cell cycle, CDKs and cancer: a changing paradigm. Nature Reviews. Cancer, 9(3), 153-166. http://doi.org/10.1038/nrc2602 
Marina, N., Gebhardt, M., Teot, L., \& Gorlick, R. (2004). Biology and therapeutic advances for pediatric osteosarcoma. The Oncologist, 9(4), 422-441.

Minville-Walz, M., Pierre, A.-S., Pichon, L., Bellenger, S., Fèvre, C., Bellenger, J., Fèvre, C., Bellenger, J., Tessier, C., Narce, M., \& Rialland, M. (2010). Inhibition of stearoyl-CoA desaturase 1 expression induces CHOP-dependent cell death in human cancer cells. PloS One, 5(12), e14363.

Mirabello, L., Troisi, R. J., \& Savage, S. A. (2009). Osteosarcoma incidence and survival rates from 1973 to 2004: Data from the surveillance, epidemiology, and end results program. Cancer, 115(7), 1531-1543. http://doi.org/10.1002/cncr.24121

Moore, J., Megaly, M., MacNeil, A. J., Klentrou, P., \& Tsiani, E. (2016). Rosemary extract reduces Akt/mTOR/p70S6K activation and inhibits proliferation and survival of A549 human lung cancer cells. Biomedicine \& Pharmacotherapy, 83, 725-732. http://doi.org/10.1016/j.biopha.2016.07.043

Mouria, M., Gukovskaya, A. S., Jung, Y., Buechler, P., Hines, O. J., Reber, H. A., \& Pandol, S. J. (2002). Food-derived polyphenols inhibit pancreatic cancer growth through mitochondrial cytochrome c release and apoptosis. International Journal of Cancer, 98(5), 761-769. http://doi.org/10.1002/ijc.10202

Nani, A., Belarbi, M., Ksouri-Megdiche, W., Abdoul-Azize, S., Benammar, C., Ghiringhelli, F., Hichami, A., \& Khan, N. A. (2015). Effects of polyphenols and lipids from Pennisetum glaucum grains on T-cell activation: modulation of $\mathrm{Ca}^{2+}$ and ERK1/ERK2 signaling. BMC Complementary and Alternative Medicine, 15(1), 426. http://doi.org/10.1186/s12906-015-0946-3

Nicotera, P., \& Orrenius, S. (1998). The role of calcium in apoptosis. Cell Calcium, 23(2), $173-180$.

Nishimoto, T. (2000). Upstream and downstream of ran GTPase. Biological Chemistry, 

381(5-6), 397-405. http://doi.org/10.1515/BC.2000.052

Nitulescu, G. M., Margina, D., Juzenas, P., Peng, Q., Olaru, O. T., Saloustros, E., Fenga, C., Spandidos, D. A., Libra, M., \& Tsatsakis, A. M. (2016). Akt inhibitors in cancer treatment: The long journey from drug discovery to clinical use (Review). International Journal of Oncology, 48(3), 869-885. http://doi.org/10.3892/ijo.2015.3306

Osaki, M., Oshimura, M., \& Ito, H. (2004). PI3K-Akt pathway: its functions and alterations in human cancer. $\quad$ Apoptosis, $\quad 9(6), \quad 667-676$. http://doi.org/10.1023/B:APPT.0000045801.15585.dd

Ouyang, L., Shi, Z., Zhao, S., Wang, F. T., Zhou, T. T., Liu, B., \& Bao, J. K. (2012). Programmed cell death pathways in cancer: A review of apoptosis, autophagy and programmed necrosis. Cell Proliferation, 45(6), 487-498. http://doi.org/10.1111/j.13652184.2012.00845.x

Pentimalli, F., \& Giordano, A. (2009). Promises and drawbacks of targeting cell cycle kinases in cancer. Discovery Medicine, 8(43), 177-180.

Perfettini, J.-L., Castedo, M., Nardacci, R., Ciccosanti, F., Boya, P., Roumier, T., Larochette, Nathanael., Piacentini, M., \& Kroemer, G. (2005). Essential role of p53 phosphorylation by p38 MAPK in apoptosis induction by the HIV-1 envelope. The Journal of Experimental Medicine, 201(2), 279-89. http://doi.org/10.1084/jem.20041502

Ramos, S. (2008). Cancer chemoprevention and chemotherapy: Dietary polyphenols and signalling pathways. Molecular Nutrition and Food Research, 52(5), 507-526. http://doi.org/10.1002/mnfr.200700326

Rastogi, N., \& Mishra, D. P. (2012). Therapeutic targeting of cancer cell cycle using proteasome inhibitors. Cell Division, 7, 26. http://doi.org/10.1186/1747-1028-7-26

Riemenschneider, M. J., Betensky, R. A., Pasedag, S. M., \& Louis, D. N. (2006). AKT activation in human glioblastomas enhances proliferation via TSC2 and S6 kinase 
signaling. Cancer Research, 66(11), 5618-5623. http://doi.org/10.1158/00085472.CAN-06-0364

Rodriguez, D., Rojas-rivera, D., \& Hetz, C. (2011). Biochimica et Biophysica Acta Integrating stress signals at the endoplasmic reticulum: The BCL-2 protein family rheostat گ̧. BBA - Molecular Cell Research, 1813(4), 564-574. http://doi.org/10.1016/j.bbamcr.2010.11.012

Roskoski, R. (2016). Cyclin-dependent protein kinase inhibitors including palbociclib as anticancer drugs. Pharmacological Research, 107, 249-275. http://doi.org/10.1016/j.phrs.2016.03.012

Shahidi, F., \& Chandrasekara, A. (2013). Millet grain phenolics and their role in disease risk reduction and health promotion: A review. Journal of Functional Foods, 5(2), 570-581.

She, Q.-B., Bode, A. M., Ma, W.-Y., Chen, N.-Y., \& Dong, Z. (2001). Resveratrol-induced activation of p53 and apoptosis is mediated by extracellular- signal-regulated protein kinases and p38 kinase. Cancer Res., 61(4), 1604-1610.

Su, C.-C., Chen, J. Y.-F., Din, Z.-H., Su, J.-H., Yang, Z.-Y., Chen, Y.-J., \& Wu, Y.-J. (2014). 13-acetoxysarcocrassolide induces apoptosis on human gastric carcinoma cells through mitochondria-related apoptotic pathways: p38/JNK activation and PI3K/AKT suppression. Marine Drugs, 12(10), 5295-5315.

Szegezdi, E., Logue, S. E., Gorman, A. M., \& Samali, A. (2006). Mediators of endoplasmic reticulum stress-induced apoptosis. EMBO Reports, 7(9), 880-885.

T, W., X, G., R, J., H, L., W, D., \& Kuang, G. (2016). Ferulic acid inhibits proliferation and promotes apoptosis via blockage of PI3K/Akt pathway in osteosarcoma cell. American Journal of Translational Research, 8(2), 968-980.

Thomasset, S. C., Berry, D. P., Garcea, G., Marczylo, T., Steward, W. P., \& Gescher, A. J. (2007). Dietary polyphenolic phytochemicals - Promising cancer chemopreventive 
agents in humans? A review of their clinical properties. International Journal of Cancer, 120(3), 451-458. http://doi.org/10.1002/ijc.22419

Torkin, R., Lavoie, J.-F., Kaplan, D. R., \& Yeger, H. (2005). Induction of caspase-dependent, p53-mediated apoptosis by apigenin in human neuroblastoma. Molecular Cancer $\begin{array}{llll}\text { Therapeutics, } & 4(1), & \text { Retrieved } & \text { from }\end{array}$ PM:15657348\nhttp://www.ncbi.nlm.nih.gov/pubmed/15657348

Vogelstein, B., Lane, D., \& Levine, a J. (2000). Surfing the p53 network. Nature, 408(6810), 307-310. http://doi.org/10.1038/35042675

Vousden, K. H., \& Prives, C. (2009). Blinded by the Light: The Growing Complexity of p53. Cell, 137(3), 413-431. http://doi.org/10.1016/j.cell.2009.04.037

Wagner, E. F., \& Nebreda, A. R. (2009). Signal integration by JNK and p38 MAPK pathways in cancer development. Nature Reviews. Cancer, 9, 537-549. http://doi.org/10.1038/nrc2694

Wang, T., Gong, X., Jiang, R., Li, H., Du, W., \& Kuang, G. (2016). Ferulic acid inhibits proliferation and promotes apoptosis via blockage of PI3K/Akt pathway in osteosarcoma cell. American Journal of Translational Research, 8(2), 968.

Xu, X., Wang, B., \& Xu, Y. (2013). Expression of lysyl oxidase in human osteosarcoma and its clinical significance: a tumor suppressive role of LOX in human osteosarcoma cells. International Journal of Oncology, 43(5), 1578-1586.

Yu, R., Hebbar, V., Kim, D. W., Mandlekar, S., Pezzuto, J. M., \& Kong, A. N. (2001). Resveratrol inhibits phorbol ester and UV-induced activator protein 1 activation by interfering with mitogen-activated protein kinase pathways. Mol Pharmacol, 60(1), 217224. Retrieved from http://www.ncbi.nlm.nih.gov/pubmed/11408617

Zechner, D., Thuerauf, D. J., Hanford, D. S., McDonough, P. M., \& Glembotski, C. C. (1997). A Role for the p38 Mitogen-activated Protein Kinase Pathway in Myocardial 

Journal of Cell Biology, 139(1), 115-127. http://doi.org/10.1083/jcb.139.1.115

693

694

695

696

697

698

699

700

701

702

703

704

705

706

707

708

709

710

711

712

713

714

715

Zeriouh, W., Nani, A., Belarbi, M., Dumont, A., de Rosny, C., Aboura, I., Ghanemi, F. Z., Murtaza, B., Patoli, D., Apetoh, L. Rébé, C. Delmas, D. Khan, N.A. Ghiringhelli, F. Rialland, M., \& Hichami, A. (2017). Correction: Phenolic extract from oleaster (Olea europaea var. Sylvestris) leaves reduces colon cancer growth and induces caspasedependent apoptosis in colon cancer cells via the mitochondrial apoptotic pathway. PloS One, 12(4), e0176574.

Zhou, W., Hao, M., Du, X., Chen, K., Wang, G., \& Yang, J. (2014). Advances in targeted therapy for osteosarcoma. Discovery Medicine, 17(96), 301-307. 


\section{Legends of figures}

717

718

719

720

721

722

723

724

725

726

727

728

729

730

731

732

733

734

735

736

737

738

739

740

741

742

Fig. 1. Effects of PGPC and p-CA on cell viability. (A) The cells (seeded at the initial cell density of $3 \times 10^{4}$ cells/well) were incubated with different concentrations of PGPC or p-CA for $24 \mathrm{~h}$ as described in Experimental Section. Cell viability was assessed by trypan blue exclusion test. Cell numbers were determined by a hemocytometer. Inserts show the release of LDH into cell culture, measured from supernatant, in response to PGPC (left panel) and p-CA (right panel) treatments. Triton X-100 (1\%) was used as a high control. Data represent the mean \pm S.D. of three independent experiments performed in triplicate $(\mathrm{n}=3)$. $^{*}, * *$, and $* * *$ represent $p<0.05, p<0.01$, and $p<0.001$ respectively as compared to untreated cells. (B) U-2OS cells morphology after $24 \mathrm{~h}$ of incubation with PGPC (60 and $100 \mu \mathrm{g} / \mathrm{mL})$ and p-CA (15000 and $25000 \mu \mathrm{M})$, as assessed by light inverted microscopy (magnification $\times 200)$.

Fig. 2. Effects of PGPC and p-CA on induction of apoptosis in U-2OS cells. (A) AnnexinV/7-AAD staining cytograms of U-2OS cells pre-incubated or not with z-VAD-fmk, and then treated with PGPC $(60 \mu \mathrm{g} / \mathrm{mL})$ or p-CA $(12500 \mu \mathrm{M})$ for $24 \mathrm{~h}$. Cytograms are representative of three independent experiments. (B) Rate of early or late apoptosis and necrosis of U-2OS cell lines. Annexin V+, 7AAD+ values were considered statistically significant if $\mathrm{p}<0.01(* *)$ when compared with untreated cells.

Fig. 3. Effects of PGPC on calcium-mediated apoptosis in U-2OS cells. (A) percentage of apoptotic cells (Annexin V positive) treated with PGPC $(60 \mu \mathrm{g} / \mathrm{mL})$ in the presence of one or combination of the following molecules: BAPTA-AM $(5 \mu \mathrm{M}), \operatorname{RuR}(5 \mu \mathrm{M}), \mathrm{zVAD}(50 \mu \mathrm{M})$, 3-MA $(5 \mathrm{mM}), \mathrm{CQ}(50 \mu \mathrm{M}){ }^{*}, * *$ and $* * *$ represent $p<0.05, p<0.01$, and $p<0.001$ respectively as compared to untreated cells. 
743

Fig. 4. Effect of PGPC on apoptosis-related proteins. "A" represents up-regulation of p-53, caspase- 8 and -9 and PARP activity in PGPC-treated U-2OS cells for $24 \mathrm{~h}$, as assessed by western blotting analysis. $\beta$-actin was used as the internal protein control. "B" represents ERmediated apoptosis proteins expression in response to U-2OS cells treatment with PGPC, as assessed by qRT PCR.

Fig. 5. $\mathrm{Ca}^{2+}$ signaling modulation by PGPC in U-2OS cells. The colored time-lapse changes in the increases in $\left[\mathrm{Ca}^{2+}\right] \mathrm{i}$ were recorded in PGPC-treated U-2OS cells in $100 \% \mathrm{Ca}^{2+}{ }_{\text {-buffer }}$ (A) or $0 \% \mathrm{Ca}^{2+}$-buffer (B). Figure $\mathrm{C}$ shows the single traces of observations which were reproduced independently $(n=3)$. The arrow head indicates the time when PGPC was added into the wells without interruptions in recordings.

Fig. 6. Effect of PGPC on ATK (A) and MAPKs pathway (B) in U-2OS cells, as assessed by western blotting. $\beta$-actin was used as the internal protein control.

Fig. 7. Effect of PGPC on cell cycle progression. (A) Cell cycle representative profile of U$2 \mathrm{OS}$ in untreated or treated cells with PGPC $(60 \mu \mathrm{g} / \mathrm{mL})$ or p-CA $(12500 \mu \mathrm{M})$ for $24 \mathrm{~h}$ then labeled with PI and analyzed by FACSCanto. (B) Statistical analysis of G1, S and G2/M phases of cell cycle in untreated and treated cells with PGPC $(60 \mu \mathrm{g} / \mathrm{mL})$ or p-CA $(12500$ $\mu \mathrm{M})$ co-treated or not with 5-FU $(2,5 \mu \mathrm{M})$. $\S$ represents $p<0.05$ in $\mathrm{S}$ phase as compared to control group, * represents $p<0.05$ in $\mathrm{S}$ phase as compared to 5-fu treated group. (C) Effects of PGPC on S phase cyclins and CDKs, as determined by western blotting analysis. $\beta$-actin was used as the internal protein control. 

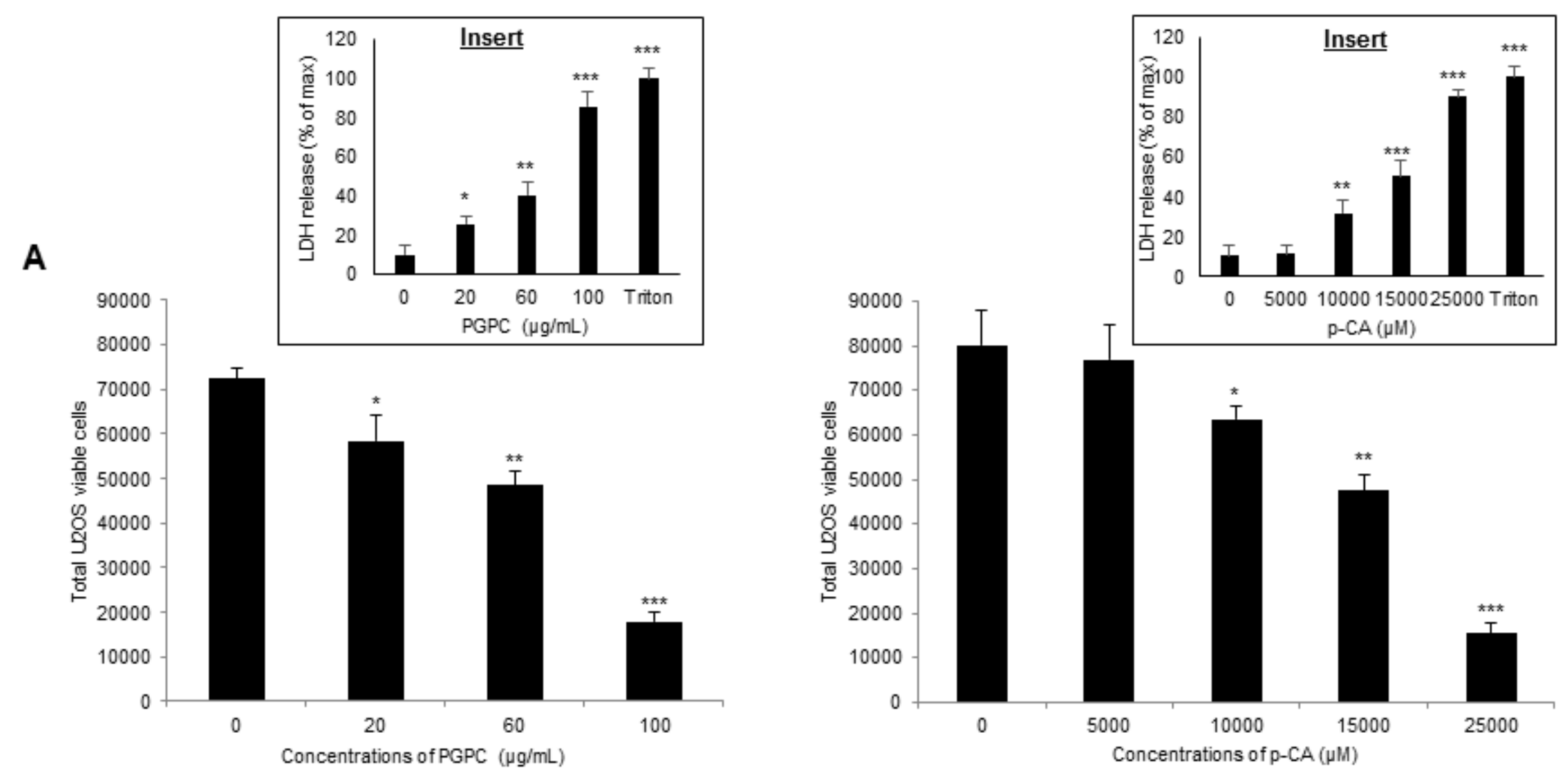

B

U2OS cells

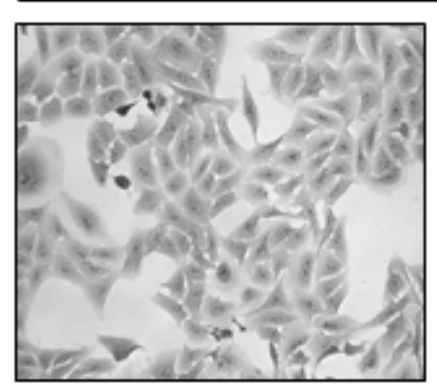

Control

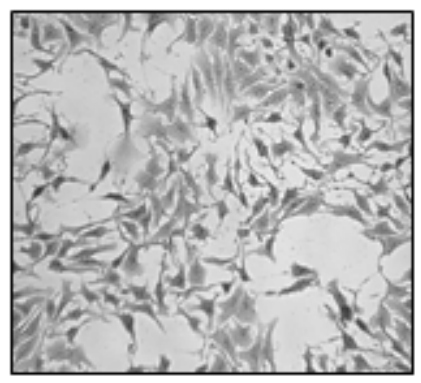

PGPC, $60 \mu \mathrm{g} / \mathrm{mL}$

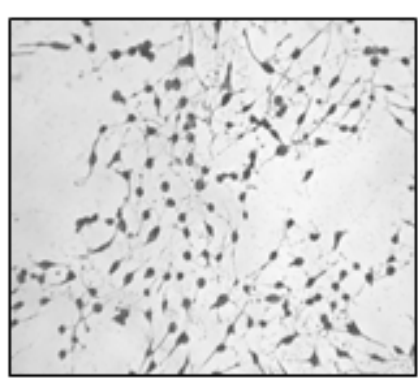

PGPC, $100 \mu \mathrm{g} / \mathrm{mL}$

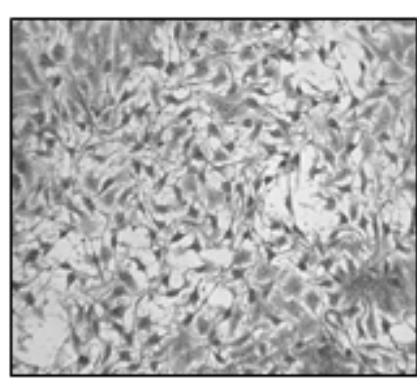

p-CA, $15000 \mu \mathrm{M}$

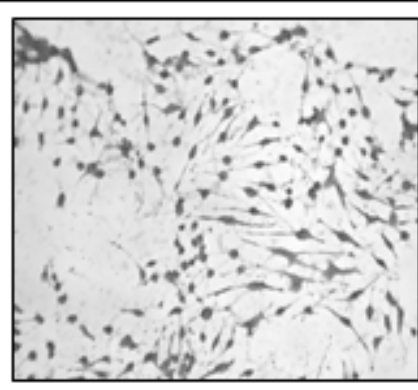

p-CA, $25000 \mu \mathrm{M}$ 

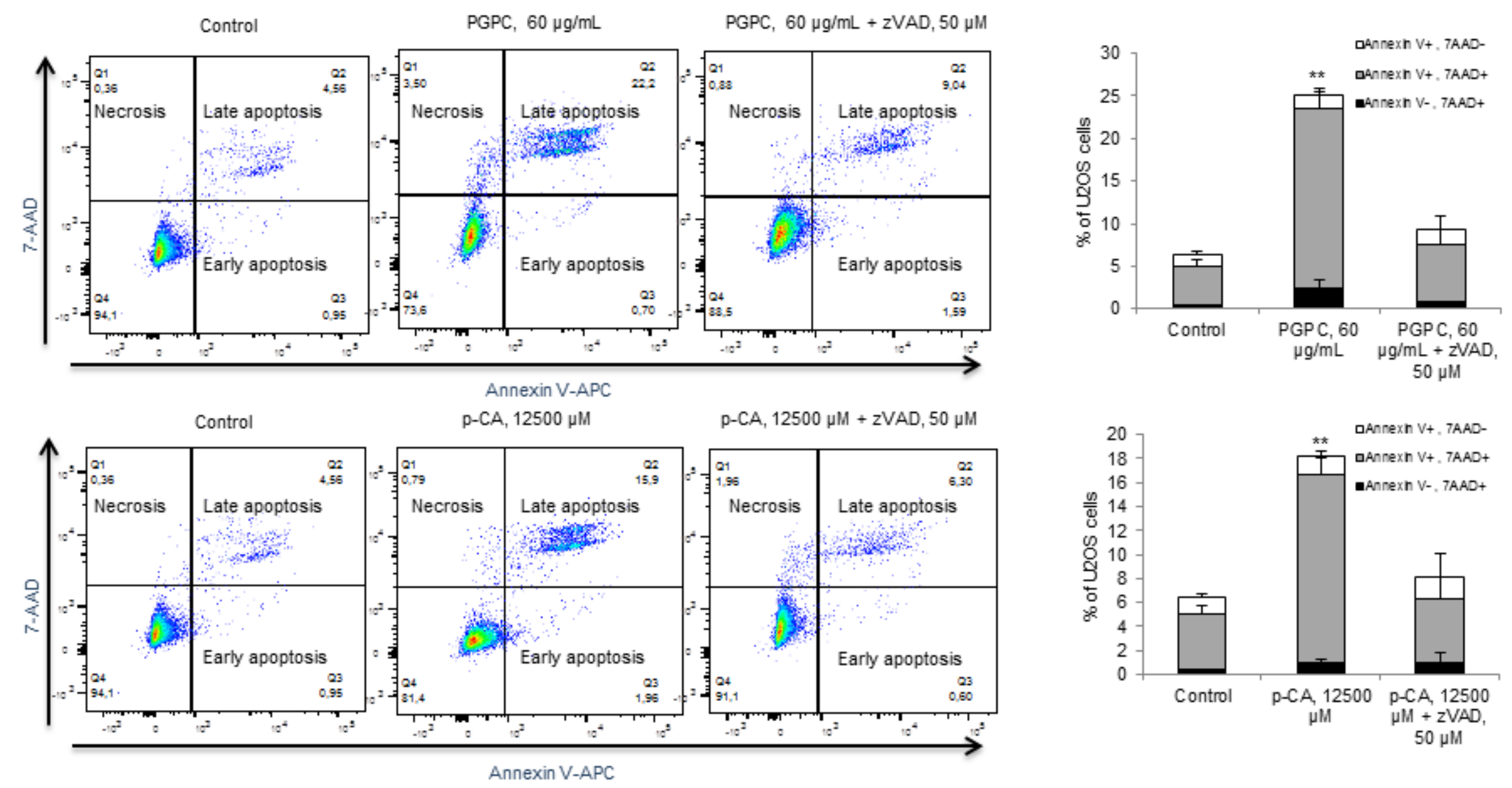


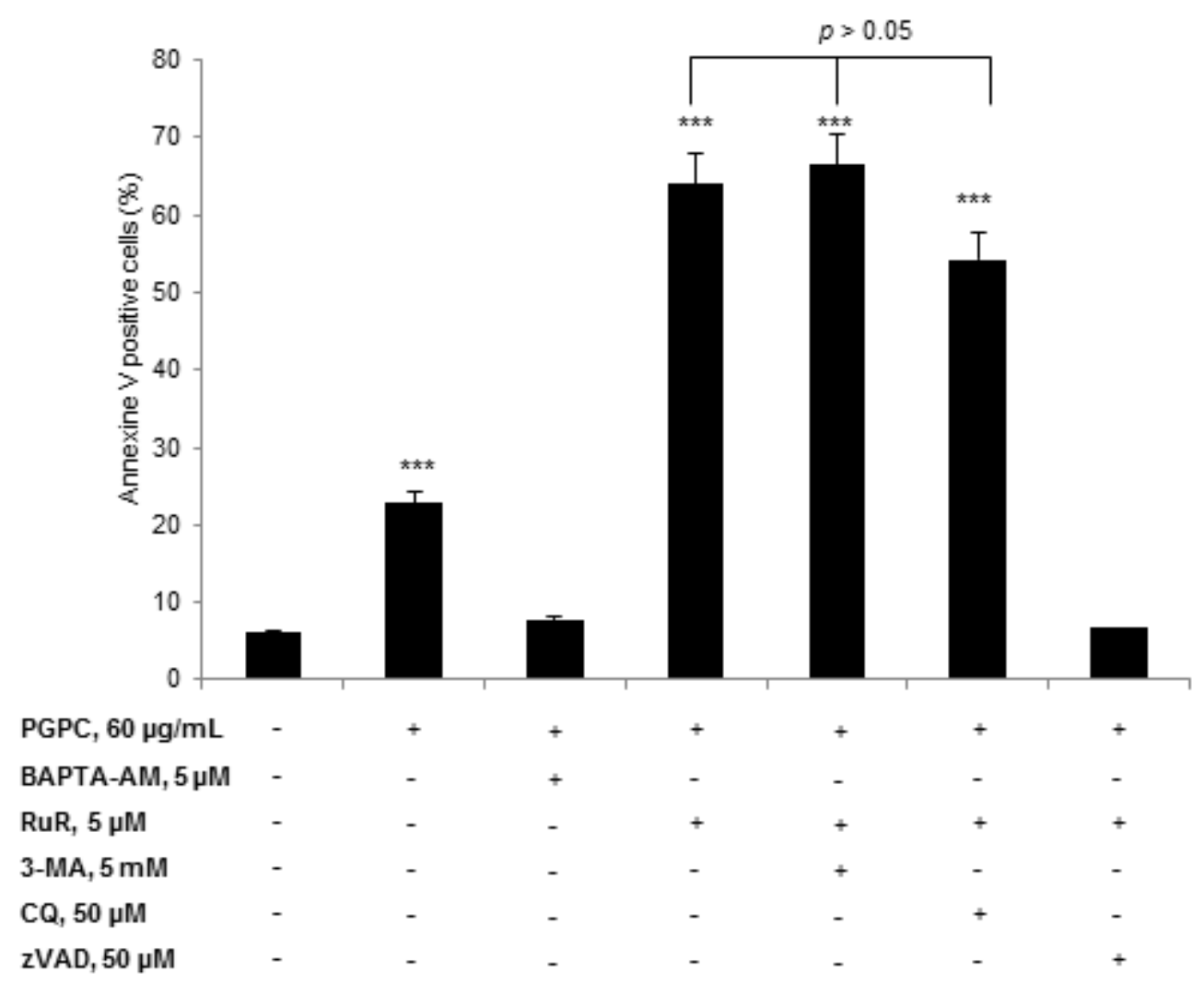


A
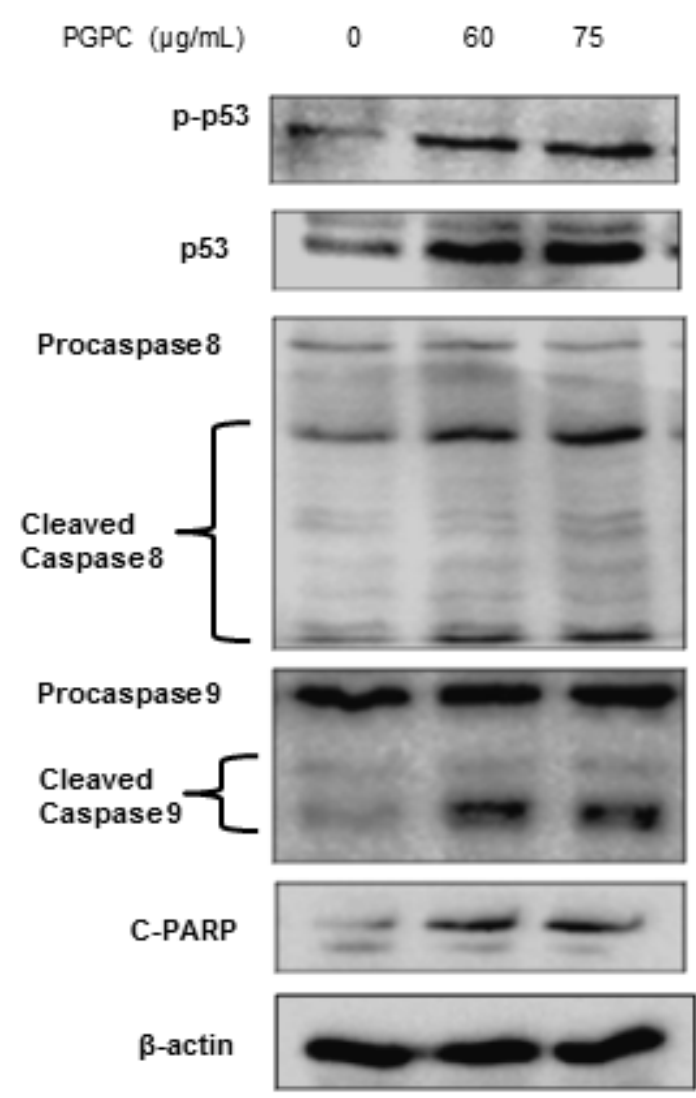

B
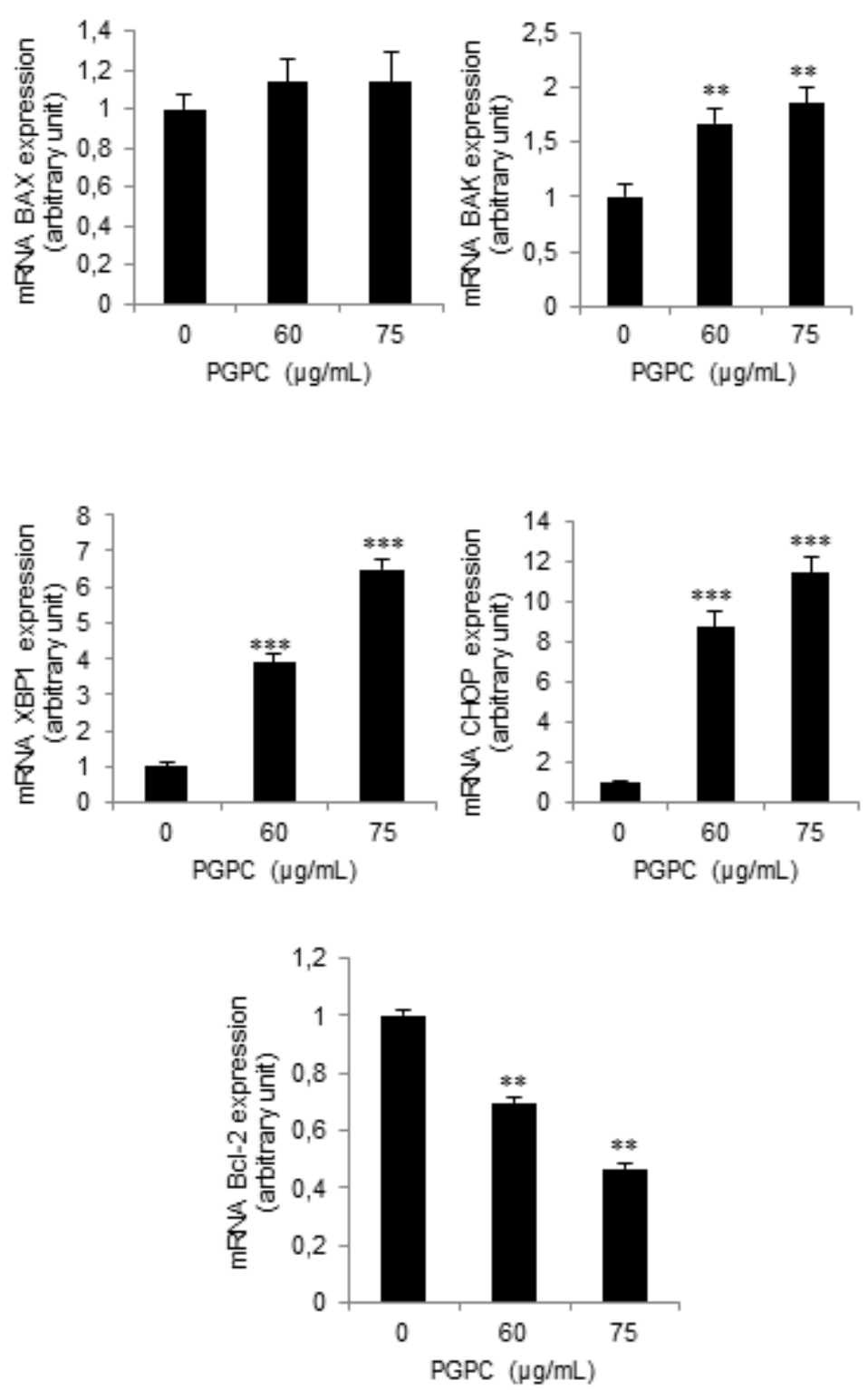

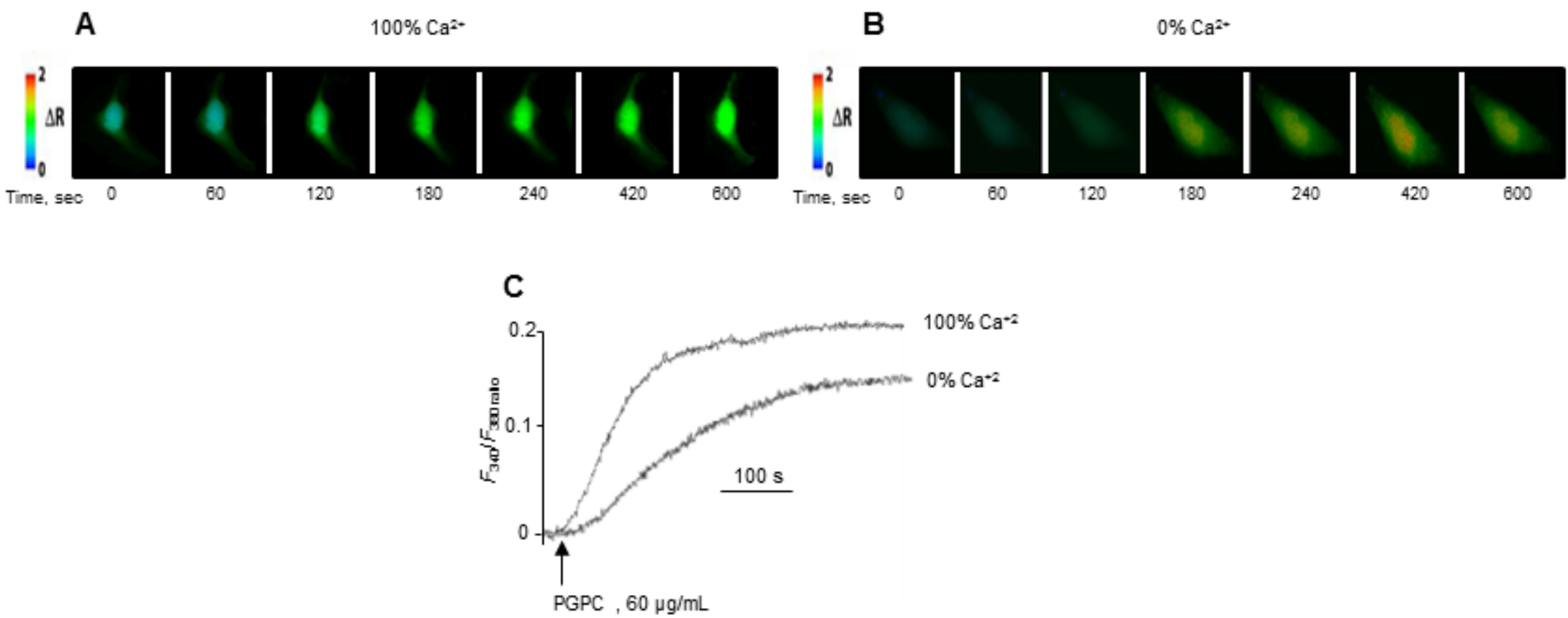
A
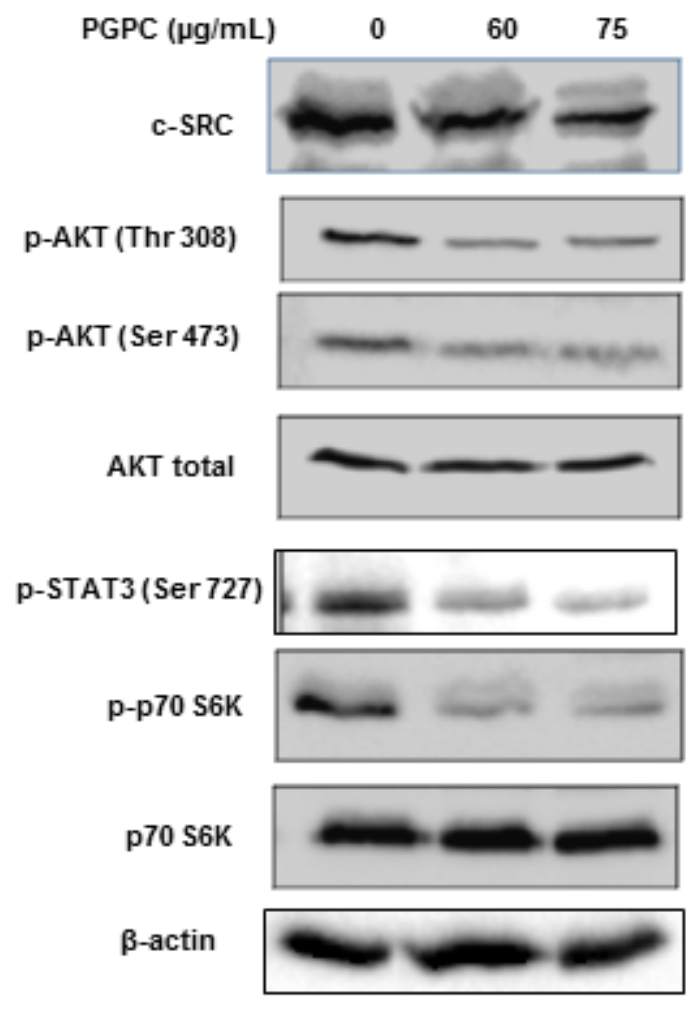

B

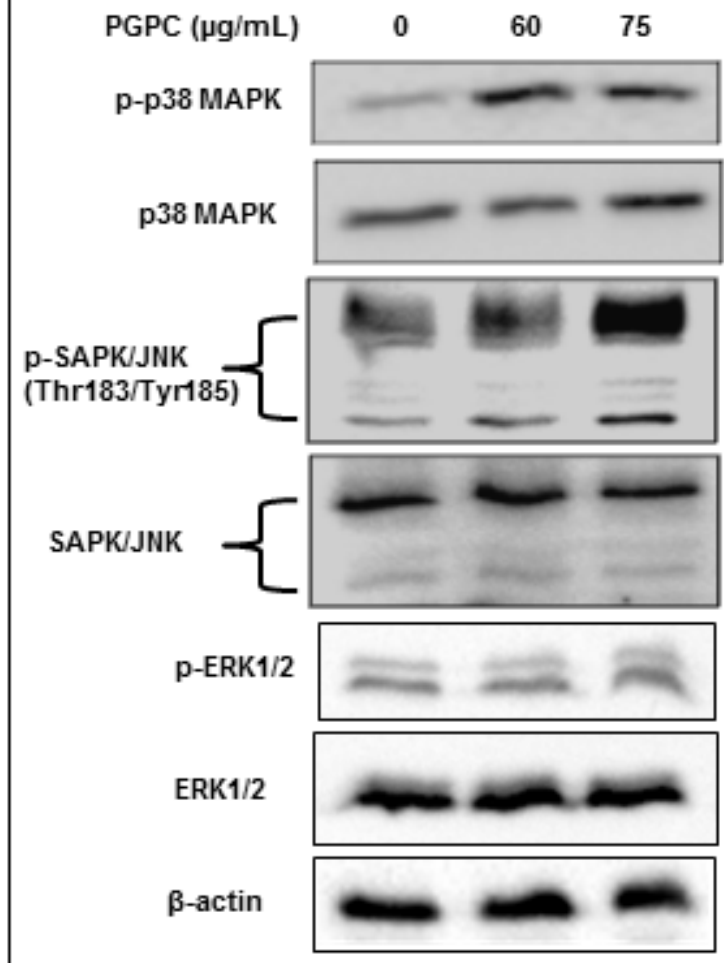


A

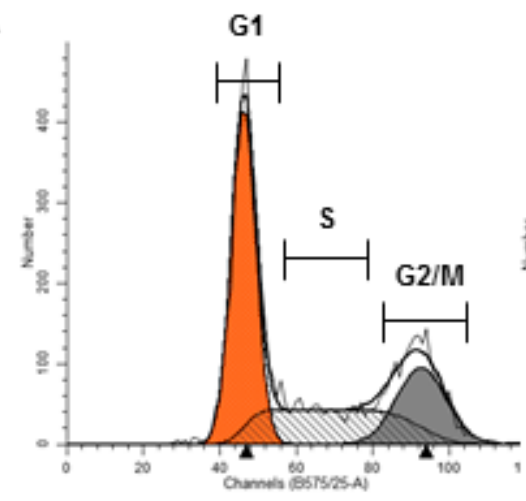

Control

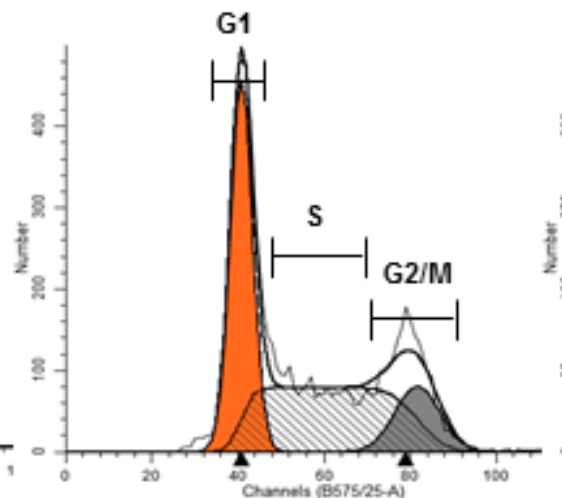

PGPC, $60 \mu \mathrm{g} / \mathrm{mL}$

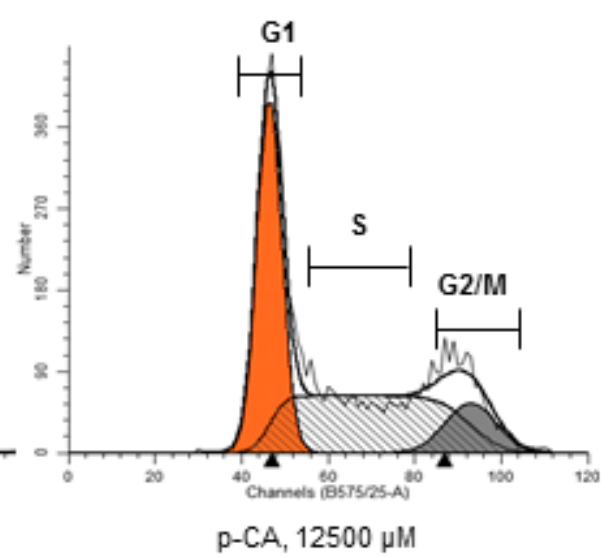

B

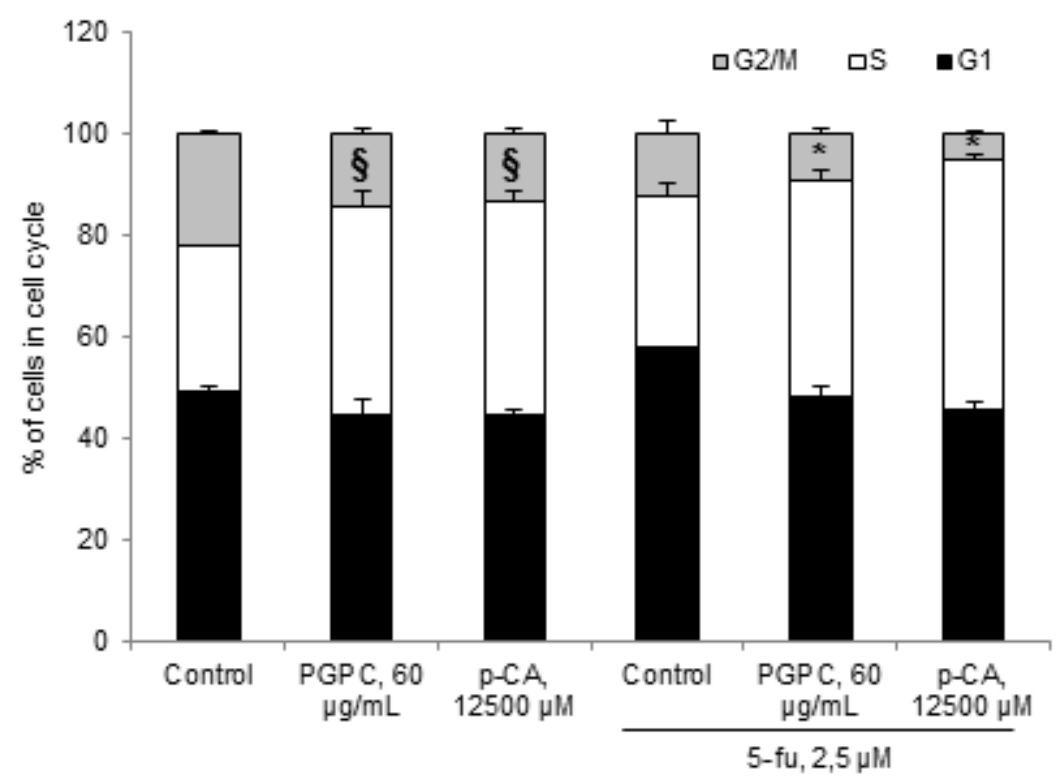

C

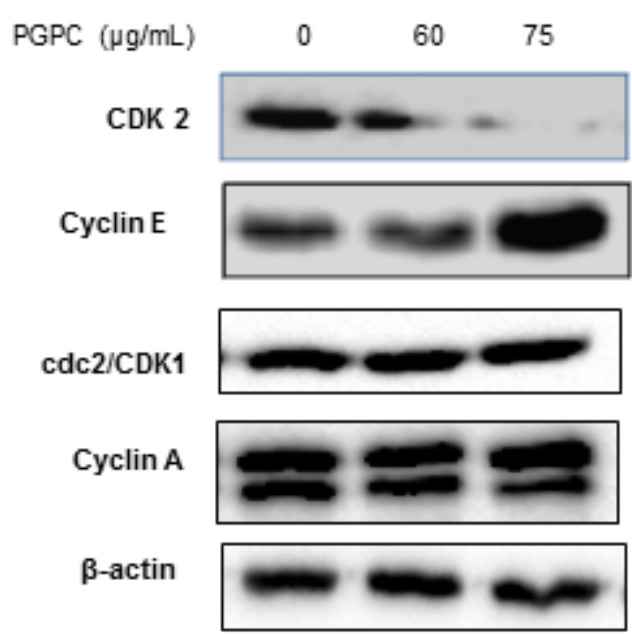

